Prepared for the U.S. Department of Energy under Contract DE-AC05-76RL01830

\title{
BP-5 Remedial Investigation Slug-Test Characterization Results for Well 699-52-55A
}

DR Newcomer

July 2008

Pacific Northwest

NATIONAL LABORATORY 


\title{
DISCLAIMER
}

This report was prepared as an account of work sponsored by an agency of the United States Government. Neither the United States Government nor any agency thereof, nor Battelle Memorial Institute, nor any of their employees, makes any warranty, express or implied, or assumes any legal liability or responsibility for the accuracy, completeness, or usefulness of any information, apparatus, product, or process disclosed, or represents that its use would not infringe privately owned rights. Reference herein to any specific commercial product, process, or service by trade name, trademark, manufacturer, or otherwise does not necessarily constitute or imply its endorsement, recommendation, or favoring by the United States Government or any agency thereof, or Battelle Memorial Institute. The views and opinions of authors expressed herein do not necessarily state or reflect those of the United States Government or any agency thereof.

\author{
PACIFIC NORTHWEST NATIONAL LABORATORY \\ operated by \\ BATTELLE \\ for the \\ UNITED STATES DEPARTMENT OF ENERGY \\ under Contract DE-AC05-76RL01830
}

Printed in the United States of America

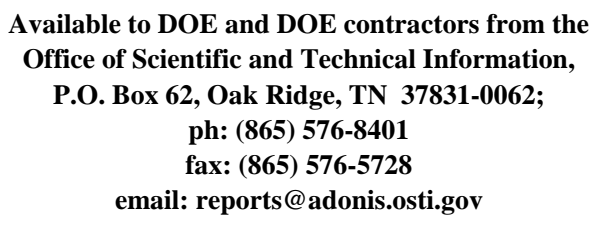

Available to the public from the National Technical Information Service, U.S. Department of Commerce, 5285 Port Royal Rd., Springfield, VA 22161 ph: (800) 553-6847 fax: (703) 605-6900

email: orders@ntis.fedworld.gov online ordering: http://www.ntis.gov/ordering.htm 


\title{
BP-5 Remedial Investigation Slug- Test Characterization Results for Well 699-52-55A
}

\author{
DR Newcomer
}

July 2008

Prepared for

the U.S. Department of Energy

under Contract DE-AC05-76RL01830

Pacific Northwest National Laboratory

Richland, Washington 99352 


\section{Summary}

Pacific Northwest National Laboratory conducted slug-test characterization at the final, completed BP-5 Remedial Investigation well 699-52-55A near the 200-East Area at the Hanford Site on April 22, 2008. The slug-test characterization was in support of the BP-5 Remedial Investigation. The portion of the unconfined aquifer tested is composed of sediments of the lower Ringold Formation and the underlying Elephant Mountain basalt flowtop. The basalt flowtop unit was included as part of the effective test-interval length for the slug-test analysis because the flowtop unit is hydraulically communicative with the unconfined aquifer. Estimates of hydraulic conductivity for the effective testinterval length represent composite values for the lower Ringold Formation and the underlying Elephant Mountain basalt flow top.

The slug-test responses for the BP-5 Remedial Investigation well 699-52-55A indicated a heterogeneous formation pattern (i.e., radial variation of hydraulic properties with distance from the well) with moderately low-permeability test conditions. The low-stress slug-test analyses for the aquifer formation at well 699-52-55A provided the most reliable estimates of hydraulic conductivity because of stress-dependence delayed effects and a slightly non-linear test response associated with the high-stress test. Hydraulic-conductivity estimates for the aquifer-formation outer radial zone ranged from $0.15 \mathrm{~m} / \mathrm{d}$ $(0.49 \mathrm{ft} / \mathrm{d})$ for the high-stress test to $0.23 \mathrm{~m} / \mathrm{d}(0.75 \mathrm{ft} / \mathrm{d})$ for the low-stress test by employing the standard type-curve analysis method. The Bouwer and Rice analysis method provided aquifer-formation estimates of hydraulic conductivity that are $\sim 10 \%$ lower (i.e., $0.13 \mathrm{~m} / \mathrm{d}[0.43 \mathrm{ft} / \mathrm{d}]$ and $0.20 \mathrm{~m} / \mathrm{d}[0.66 \mathrm{ft} / \mathrm{d}]$, respectively) than estimates provided by the type-curve method. This is consistent with comparison of results between these slug-test analysis methods reported in Butler (1998). The Bouwer and Rice analysis estimates of hydraulic conductivity for the artificially created inner radial zone ranged from $1.4 \mathrm{~m} / \mathrm{d}$ ( $4.6 \mathrm{ft} / \mathrm{d}$ ) for the high-stress test to $1.7 \mathrm{~m} / \mathrm{d}(5.6 \mathrm{ft} / \mathrm{d})$ for the low-stress test. Moderately low permeability test conditions and a relatively thin test interval at well 699-52-55A indicate that the unconfined aquifer is not very transmissive at this well location compared to most other well locations in the general 200-East Area. 



\section{Acknowledgments}

Those acknowledged include Rob Edrington of Fluor Hanford for coordinating the slug-testing activities and Olin Amos and Mike Weakley of Energy Solutions for providing field support and test equipment. Frank Spane of Pacific Northwest National laboratory (PNNL) provided technical peer review comments, Dave Lanigan of PNNL provided graphics support, and Wayne Cosby of PNNL provided editorial comments. Craig Swanson of Fluor Hanford and Jeff Serne of PNNL also provided technical review comments. 



\section{Contents}

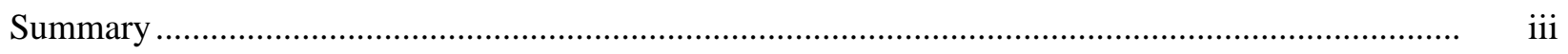

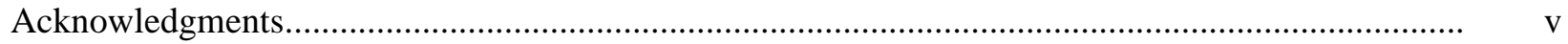

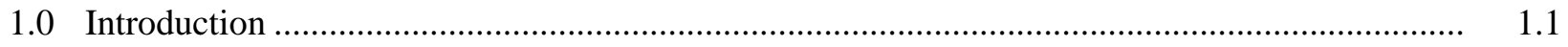

2.0 Hydrologic Test System Description........................................................................... 2.1

3.0 Slug-Test Response and Analysis........................................................................................

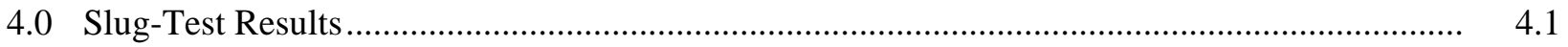

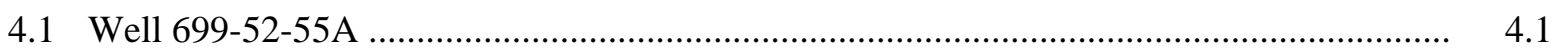

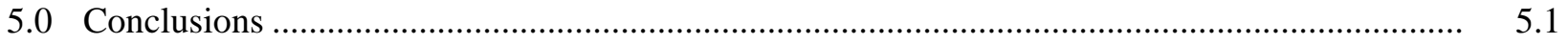

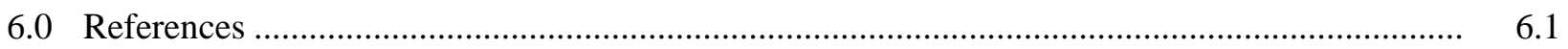

Appendix A: Well Summary Sheet for Well 699-52-55A ............................................................. A.1

Appendix B: Borehole Log for Well 699-52-55A …..................................................................... B.1

Appendix C: Slug-Test Field Notes for Well 699-52-55A ….......................................................... C.1

Appendix D: Slug-Test SW \#2 Plots for Well 699-52-55A ......................................................... D.1

\section{Figures}

1.1. Map Showing Location of BP-5 Remedial Investigation Well 699-52-55A Tested ................... 1.2

2.1. General Slug-Test Configuration within Well 699-52-55A .................................................. 2.2

3.1. Diagnostic Slug-Test Response (taken from Spane and Newcomer 2008) .............................. 3.2

3.2. Over-Damped Slug-Test Response as a Function of Test-Interval Hydraulic Conductivity ....... 3.3

4.1. Diagnostic Analysis Plot for Well 699-52-55A........................................................................

4.2. Comparison of Low-Stress and High-Stress Slug-Test Responses for Well 699-52-55A........... 4.5

4.3. Selected Type-Curve Analysis Plot for Well 699-52-55A ...................................................... 4.6

4.4. Selected Bouwer and Rice Analysis Plot for Outer Zone, Well 699-52-55A........................... 4.7

4.5. Selected Bouwer and Rice Analysis Plot for Inner Zone, Well 699-52-55A ............................

\section{Tables}

4.1. Slug-Test Characteristics for the Test/Depth Interval at BP-5 Remedial Investigation

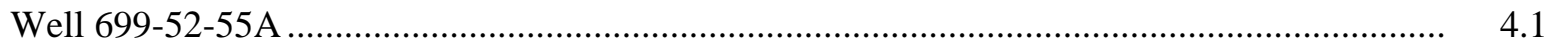

4.2. Slug-Test Analysis Results for BP-5 Remedial Investigation Well 699-52-55A ..................... 4.1 


\subsection{Introduction}

Pacific Northwest National Laboratory conducted two different stress-level slug tests at well 699-5255A, which is located north of the 200-East Area at the Hanford Site (Figure 1.1). The purpose of the slug tests was to provide hydraulic property information for the unconfined aquifer at the well 699-5255A location. This type of areal characterization information is important for predicting/simulating contaminant migration (i.e., numerical flow/transport modeling) and designing proper monitor-well strategies within this area.

Section 2 describes the general hydrologic test system employed to perform the two slug tests. Section 3 discusses slug-test response and analysis methods. Section 4 presents pertinent information describing slug-testing activities and analysis results for the test/depth interval that was hydrologically characterized at this BP-5 well. Conclusions and references are provided in Sections 5 and 6, respectively. A well summary sheet is provided in Appendix A, a borehole lithologic log is presented in Appendix B, slug-test field notes are provided in Appendix C, and additional slug-test plots are shown in Appendix D. 


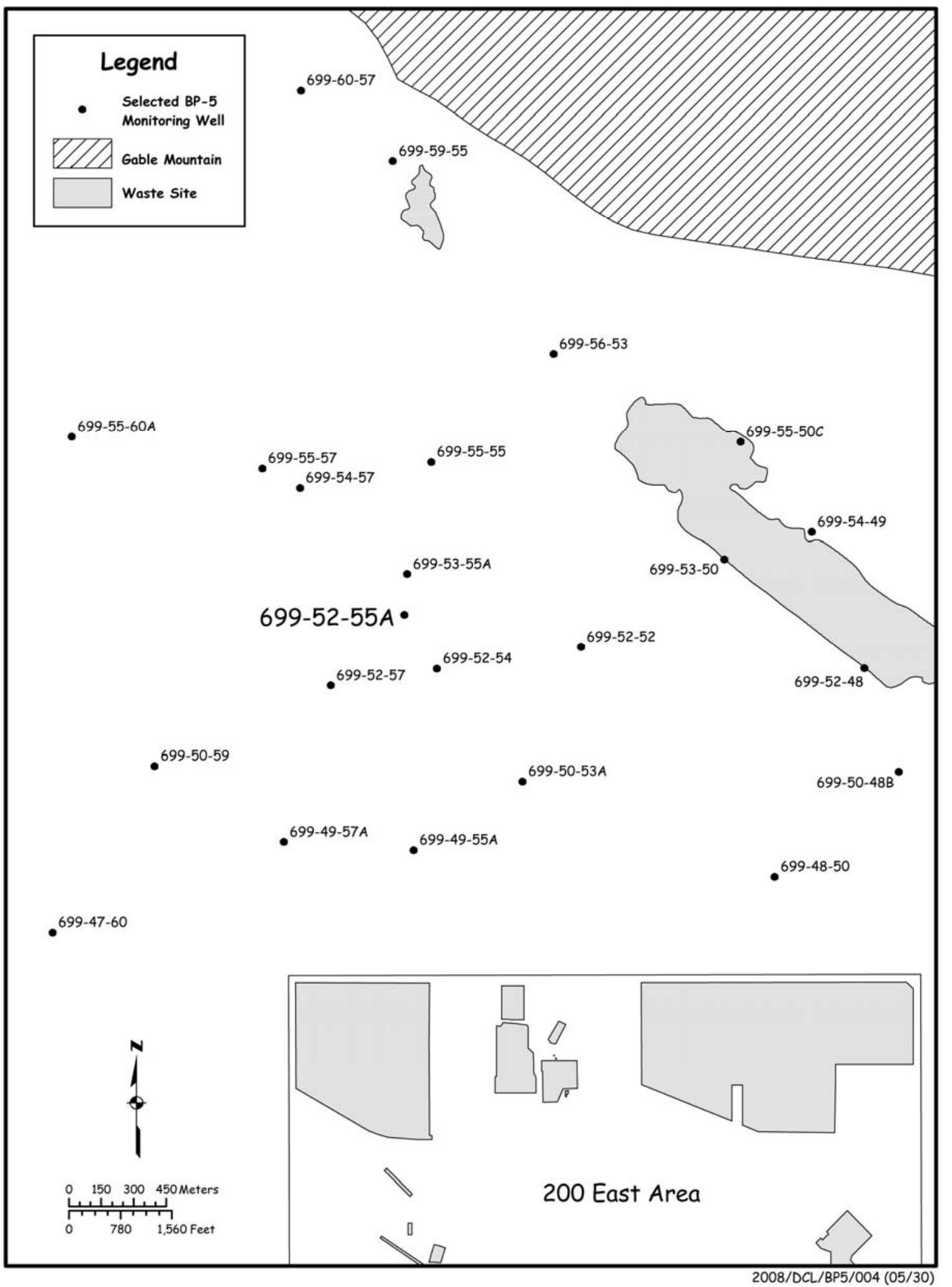

Figure 1.1. Map Showing Location of BP-5 Remedial Investigation Well 699-52-55A Tested 


\subsection{Hydrologic Test System Description}

The following discussion of the general hydrologic test plan is taken primarily from similar slug-test characterization-program descriptions presented previously by Spane. ${ }^{\text {(a) }}$ Hydrologic testing was implemented within the final well screen after the well was completed. Two different, stress-level slug withdrawal tests were conducted within the test-interval section. The reason for using a multi-stress-level approach was to determine whether the associated slug-test responses exhibited either a variable or stresslevel dependence. As noted in Butler (1998) and Spane et al. (2003a), tests exhibiting either variable or stress-level dependence can provide valuable information pertaining to the presence of dynamic well skin or non-linear (i.e., turbulence) test-response conditions occurring within the test section. The slug tests were initiated using two slugging rods of different, known displacement volumes. The slugging rods were lowered slowly into the fluid column until the rods were completely submerged. Water-level pressures were allowed to reach full recovery before initiating the slug-withdrawal tests. Because the test-depth interval was composed of low-permeability Ringold Formation sediments resting on the Elephant Mountain Basalt, the recovery times of the slug-withdrawal tests were expected to be several minutes or longer.

Figure 2.1 shows the general slug-test configuration for well 699-52-55A. The test-system configuration within the well-screen section included a downhole pressure transducer, a slugging rod lowered by a drilling rig, and a surface data-logger system. The 20-slot (0.020-in.) well-screen section had a length of $3.0 \mathrm{~m}$ (10 ft) and an I.D. dimension of $0.102 \mathrm{~m}$ (4 in.). A Druck, Inc. pressure transducer strain-gauge, 0 - to 34.5-kPa (0- to 5-psig) pressure transducer was installed below the fluid-column surface within the well-screen section to monitor the downhole test-interval response during slug testing. Pressure-transducer measurements were recorded with a Campbell Scientific, Inc. model CR-10X ${ }^{\mathrm{TM}}$ data logger and downloaded to a portable laptop computer. Details of the well construction are provided in the well summary sheet (Appendix A).

(a) FA Spane, Jr. 2003. Slug Test Characterization Results for Multi- Test/Depth Intervals Conducted During the Drilling of WMA-C Well 299-E27-22 (C4124). Letter report to Jane Borghese (Fluor Hanford, Inc.), October 8, 2003.

FA Spane FA, Jr. 2005a. Slug Test Characterization Results for Multi-Test/Depth Intervals Conducted During the Drilling of WMA-BX-BY Well 299-E33-49. Letter report to Jane Borghese (Fluor-Hanford, ORP), January 10, 2005.

Spane FA, Jr. 2005b. Slug Test Characterization Results for Multi-Test/Depth Intervals Conducted During the Drilling of CERCLA Operable Unit UP-1 Wells 299-W19-48, 699-30-66, and 699-36-70B. Letter report to Mark Byrnes (Fluor-Hanford, ORP), September 13, 2005.

Spane FA, Jr. 2005c. Slug Test Characterization Results for Multi-Test/Depth Intervals Conducted During the Drilling of CERCLA Operable Unit ZP-1 Wells 299-W11-43, 299-W15-50, and 299-W18-16. Letter report to Mark Byrnes (Fluor-Hanford, ORP), September 13, 2005. 


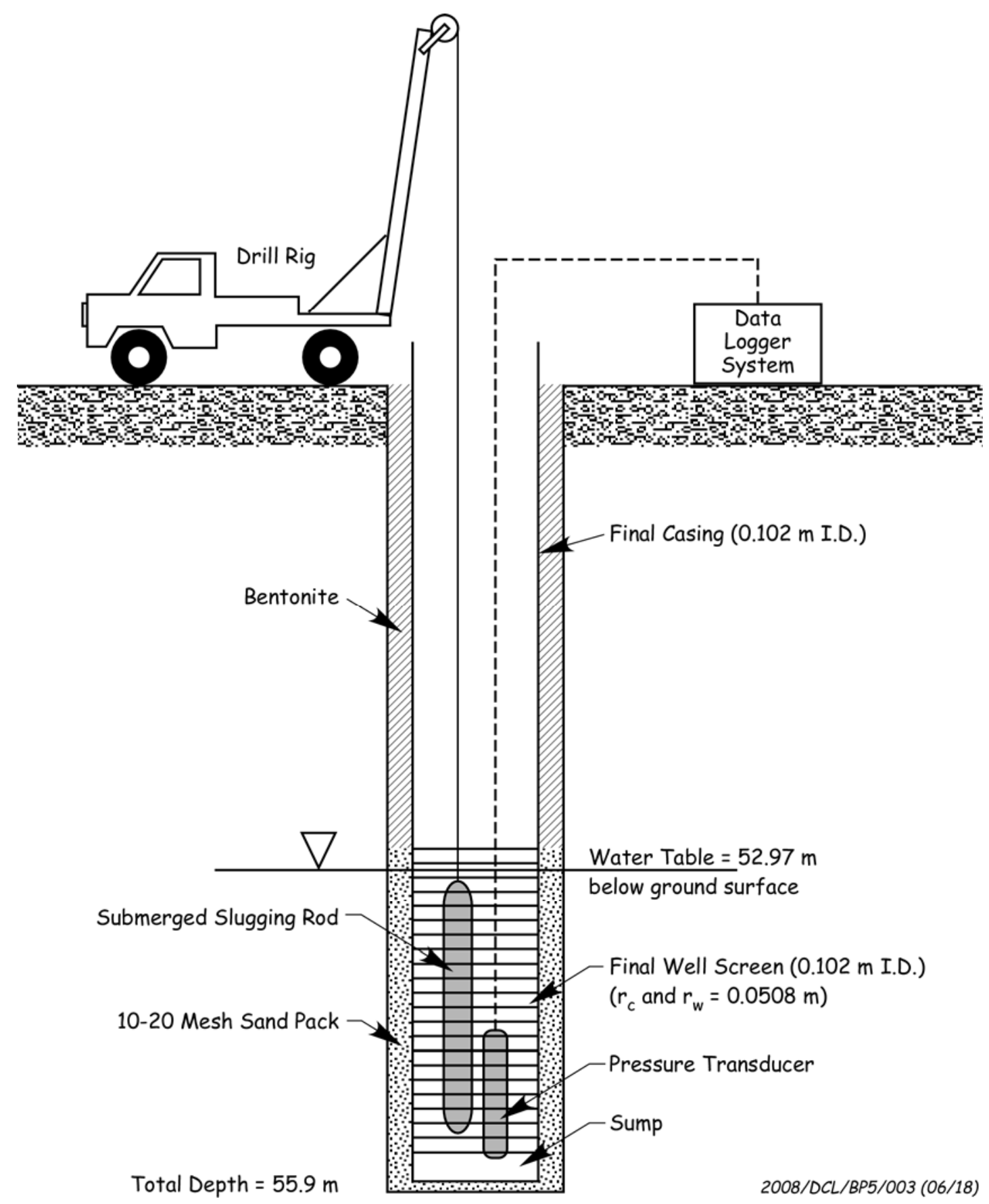

Figure 2.1. General Slug-Test Configuration within Well 699-52-55A 


\subsection{Slug-Test Response and Analysis}

The following discussion pertaining to slug-test response and analysis is taken primarily from Spane. ${ }^{\left({ }^{c}\right)}$ As shown in Figure 3.1 and discussed in Butler (1998) and Spane et al. (2003a), water levels within a test well can respond in one of three ways to the instantaneously applied stress of a slug test. These response model patterns are 1) an over-damped response, where the water levels recover in an exponentially decreasing recovery pattern, 2) an under-damped response, where the slug-test response oscillates above and below the initial static, with decreasing peak amplitudes with time, and 3) a critically damped response, where the slug-test behavior exhibits characteristics that are transitional to the overand under-damped response patterns. Factors that control the type of slug-test response model that is exhibited within a well include a number of aquifer properties (hydraulic conductivity) and welldimension characteristics (well-screen length, well-casing radius, well-radius, aquifer thickness [b], fluidcolumn length) and can be expressed by the response-damping parameter, $\mathrm{C}_{\mathrm{D}}$, which Butler (1998) reports for unconfined aquifer tests as:

$$
C_{D}=\sqrt{\frac{g}{L_{e}}} * \frac{r_{c}^{2} \ln \left[R_{e} / r_{w}\right]}{2 K L}
$$

where $\mathrm{g}=$ acceleration due to gravity, $\mathrm{m} / \mathrm{s}^{2}$

$\mathrm{L}_{\mathrm{e}}=$ effective well water-column length, $\mathrm{m}$

$\mathrm{r}_{\mathrm{C}}=$ well casing radius, $\mathrm{m}$; i.e., radius of well water-column that is active during testing

$\mathrm{R}_{\mathrm{e}}=$ effective test radius parameter, $\mathrm{m}$; as defined by Bouwer and Rice (1976)

$\mathrm{r}_{\mathrm{w}}=$ well radius of well-screen length, $\mathrm{m}$

$\mathrm{K}=$ hydraulic conductivity of test interval length, $\mathrm{m} / \mathrm{sec}$

$\mathrm{L}=$ well-screen length, $\mathrm{m}$.

(c) FA Spane, Jr. 2003. Slug Test Characterization Results for Multi- Test/Depth Intervals Conducted During the Drilling of WMA-C Well 299-E27-22 (C4124). Letter report to Jane Borghese (Fluor Hanford, Inc.), October 8, 2003.

FA Spane FA, Jr. 2005a. Slug Test Characterization Results for Multi-Test/Depth Intervals Conducted During the Drilling of WMA-BX-BY Well 299-E33-49. Letter report to Jane Borghese (Fluor-Hanford, ORP), January 10, 2005.

Spane FA, Jr. 2005b. Slug Test Characterization Results for Multi-Test/Depth Intervals Conducted During the Drilling of CERCLA Operable Unit UP-1 Wells 299-W19-48, 699-30-66, and 699-36-70B. Letter report to Mark Byrnes (Fluor-Hanford, ORP), September 13, 2005.

Spane FA, Jr. 2005c. Slug Test Characterization Results for Multi-Test/Depth Intervals Conducted During the Drilling of CERCLA Operable Unit ZP-1 Wells 299-W11-43, 299-W15-50, and 299-W18-16. Letter report to Mark Byrnes (Fluor-Hanford, ORP), September 13, 2005. 


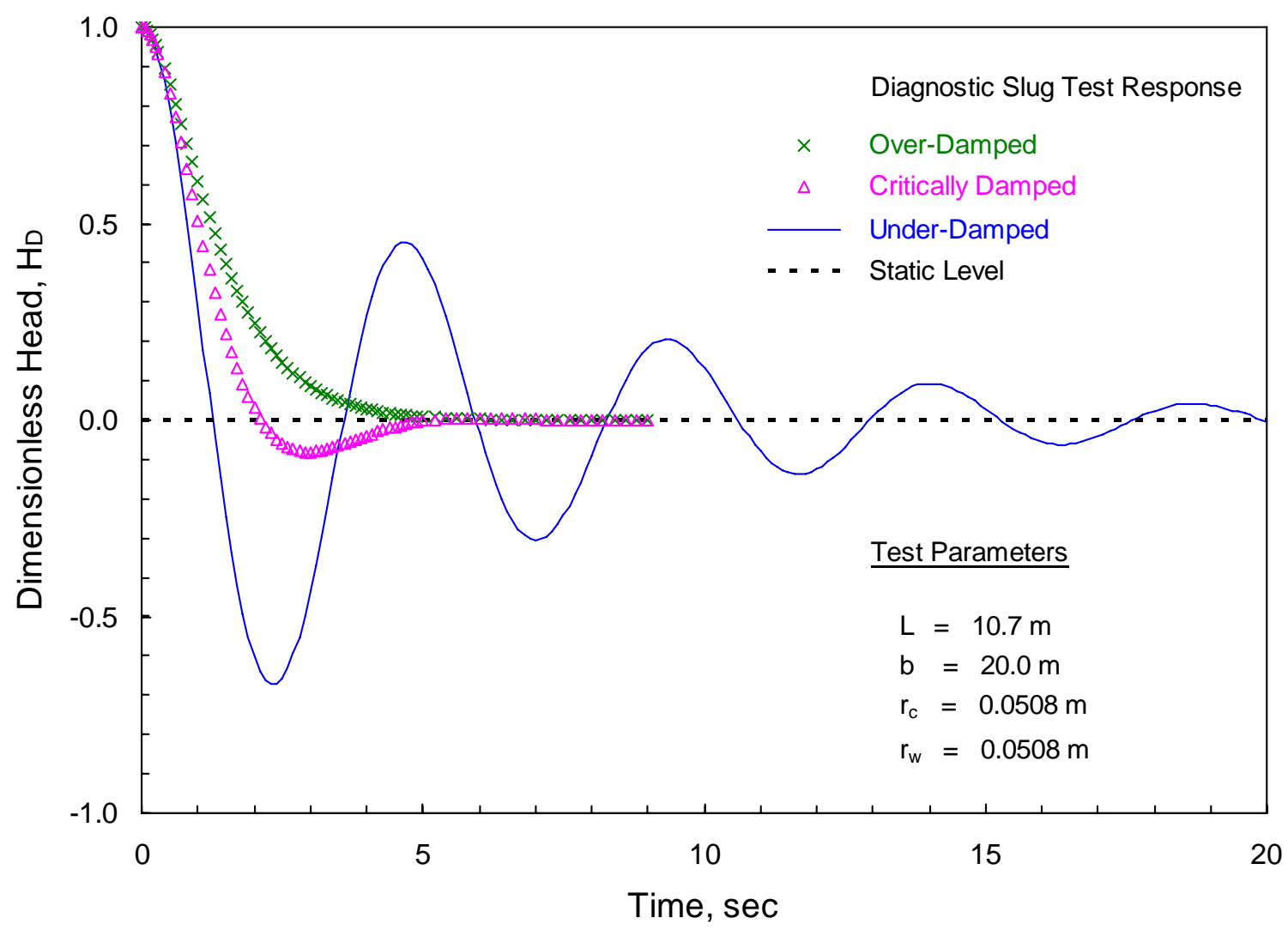

Figure 3.1. Diagnostic Slug-Test Response (taken from Spane and Newcomer 2008)

Given the multitude of possible combinations of aquifer properties, well-casing dimensions, and testinterval lengths, no universal $C_{D}$ value ranges can be provided that describe slug-test response conditions. However, the following general guidelines on predicting slug-test responses are provided:

- $\mathrm{C}_{\mathrm{D}}>3=$ over-damped response

- $\mathrm{C}_{\mathrm{D}} 1-3=$ critically damped response

- $\mathrm{C}_{\mathrm{D}}<1=$ under-damped response.

An over-damped test response generally occurs within stress wells monitoring test formations of low to moderately high hydraulic conductivity (e.g., Ringold Formation) and are indicative of test conditions where frictional forces (i.e., resistance of groundwater flow from the test interval to the well) are predominant over test-system (i.e., Equation [3.1] parameters) inertial forces. Figure 3.2 shows predicted slugtest recovery as a function of hydraulic conductivity $\left(\mathrm{K}^{(\mathrm{d})}\right.$ range: 0.1 to $10 \mathrm{~m} / \mathrm{d}$ [0.3 to $33 \mathrm{ft} / \mathrm{d}$ ]; specific storage, $S_{s}=0.00001 \mathrm{~m}^{-1}$; ratio of vertical to horizontal hydraulic conductivity, $K_{D}=1.0$; and $1.0-\mathrm{m}$ [3.3-ft] test interval length) for test interval lengths exhibiting over-damped response characteristics and general test conditions at well 699-52-55A. As indicated in the figure, test interval lengths having hydraulic conductivity values of approximately $10 \mathrm{~m} / \mathrm{d}$ (33 ft/d) or less should be readily resolved for tests exhibiting over-damped slug-test behavior. For over-damped slug tests, two different methods can be used for the slug-test analysis: the semi-empirical, straight-line analysis method described in Bouwer

(d) K refers to radial (i.e., horizontal) hydraulic conductivity throughout this report 
and Rice (1976) and Bouwer (1989) and the type-curve-matching method for unconfined aquifers presented in Butler (1998). For over-damped slug tests, hydraulic-conductivity estimates obtained with the Bouwer and Rice analytical method are generally less reliable than corresponding estimates obtained with the type-curve-matching method, particularly for aquifer formations that behave elastically (Hyder and Butler 1995; Butler 1998). However, results of the Bouwer and Rice method are generally consistent with type-curve analysis results if the aquifer formation is thin, and therefore behaves inelastically, as is the case at the 699-52-55A well location. A detailed description of over-damped, slug-test-analysis methods is presented in Spane and Newcomer (2004).

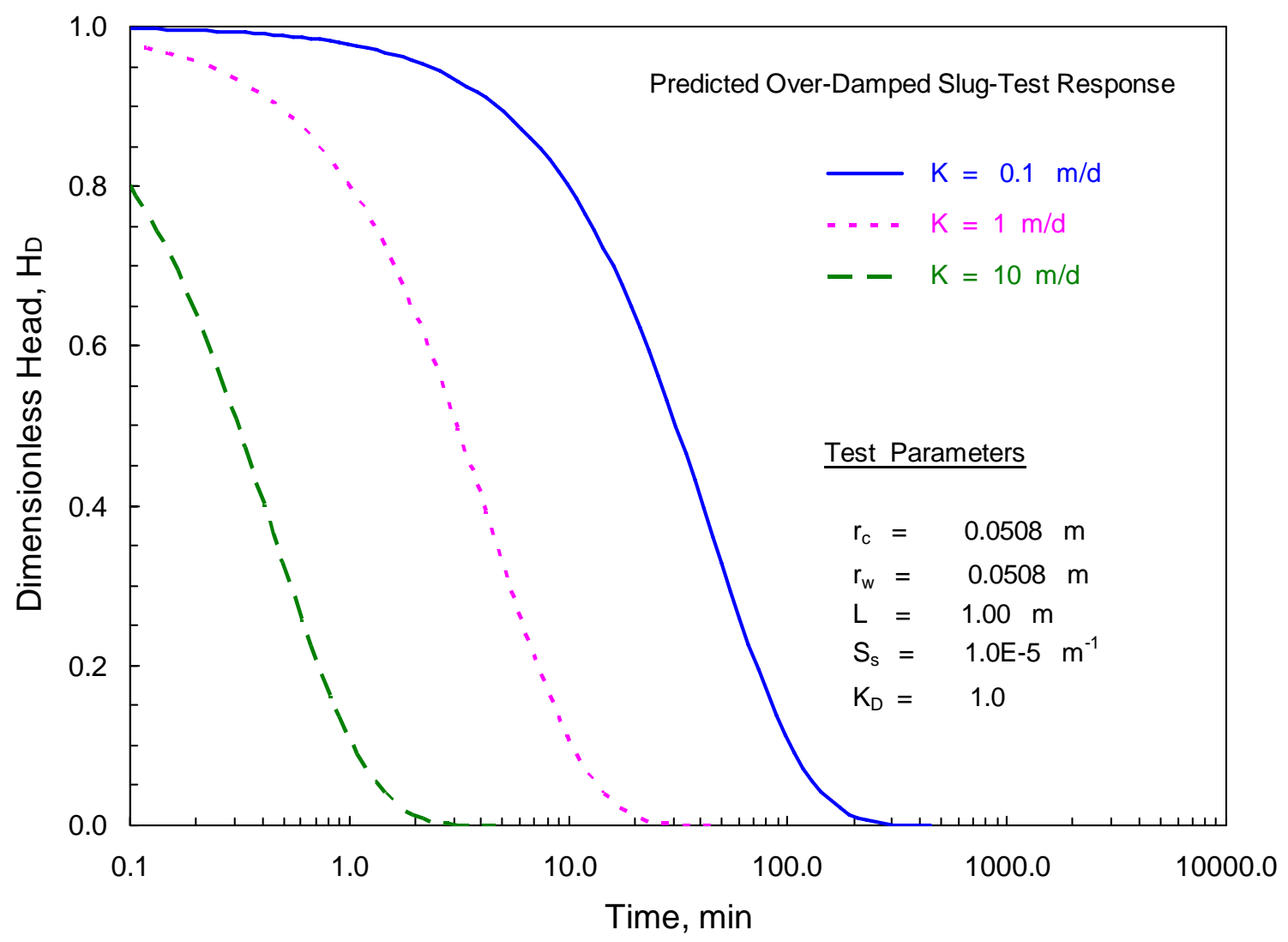

Figure 3.2. Over-Damped Slug-Test Response as a Function of Test-Interval Hydraulic Conductivity

Under-damped test-response patterns are exhibited within stress wells where inertial forces are predominant over formational frictional forces. This commonly occurs in wells with extremely long fluid columns (i.e., large water mass within the well column) and/or that penetrate highly permeable aquifers (e.g., Hanford formation). Tests exhibiting under-damped behavior should be conducted with very small stress-level applications. The slug-test response at well 699-52-55A did not exhibit an under-damped testresponse pattern.

As mentioned previously, critically damped test responses are indicated by stress well water-level responses that are transitional between the over- and under-damped test conditions, as shown in Figure 3.1. They typically occur in wells that monitor test formations exhibiting intermediate to high hydraulic conductivity. As noted in Butler (1998), distinguishing between slug-test responses that are 
over damped and critically damped may be difficult in some cases (i.e., due to test signal noise) when examined on arithmetic plots. Proper model identification may be enhanced when semi-log plots are used, i.e., log head versus time (e.g., Bouwer and Rice plot). Critically damped slug tests exhibit a diagnostic concave-downward pattern when plotted in this semi-log plot format. This is in contrast to over-damped response behavior, which displays either a linear or concave upward (elastic) pattern. Critically damped slug-test responses are influenced by processes (e.g., inertial) that are not accounted for in the previously discussed slug-test analytical methods (i.e., for over-damped tests). Because of this, slug tests exhibiting these response characteristics cannot be analyzed quantitatively with the Bouwer and Rice or standard type-curve methods. High-K analysis methods that can be employed for analyzing unconfined aquifer tests exhibiting response behavior that is either critically damped or under damped include those described in Springer and Gelhar (1991), Butler (1998), McElwee and Zenner (1998), McElwee (2001), Butler and Garnett (2000), and Zurbuchen et al. (2002). Because of the ease provided by a spreadsheet-based approach, the test-analysis method presented in Butler and Garnett (2000) is preferred for analyzing tests exhibiting critically damped behavior. A detailed discussion of this analytical procedure and method is presented in Spane and Newcomer (2004). The slug-test response at well 699-52-55A did not exhibit a critically damped test-response pattern.

Well 699-52-55A is screened across the water table, and the well-screen sand filter pack has a relatively high permeability compared to the permeability of the aquifer formation. Because of this test condition, the actual stress level imposed by the slugging rods on the test formation was lower than the theoretical stress level. This is due to the added pore volume of the sand filter pack at the time of slugtest initiation. For this test situation, the actual slug-test stress level is determined by projecting the observed early test response using linear regression back to the time of test initiation on a semi-log plot. For this case where the observed or projected slug-test stress level, $\mathrm{H}_{\mathrm{p}}$, is less than the theoretical stress level, $\mathrm{H}_{\mathrm{o}}$, an equivalent well radius, $\mathrm{r}_{\mathrm{eq}}$, must be used instead of the actual well casing radius, $\mathrm{r}_{\mathrm{c}}$, in the analytical methods. The $\mathrm{r}_{\text {eq }}$ value can be calculated by using the following relationship presented in Butler (1998):

$$
r_{e q}=r_{c}\left(H_{o} / H_{p}\right)^{1 / 2}
$$




\subsection{Slug-Test Results}

The following discussion presents pertinent information describing slug-testing activities and analysis results for the final, completed BP-5 Remedial Investigation well 699-52-55A. Table 4.1 presents slugtest information for the test/depth interval, while Table 4.2 summarizes the slug-test-analysis results. A geologic borehole log summary is provided in Appendix B, which can be referred to for a geologic description of the respective test/depth interval. The slug-test field notes for this well are provided in Appendix C. Additional slug-test plots are shown in Appendix D. The slug-test data are not included in this report due to the large volume of spreadsheet file data, but can be found in the project files.

Table 4.1. Slug-Test Characteristics for the Test/Depth Interval at BP-5 Remedial Investigation Well 699-52-55A

\begin{tabular}{|c|c|c|c|c|c|c|}
\hline \multirow[b]{2}{*}{$\begin{array}{l}\text { Test Well } \\
\text { Number }\end{array}$} & \multirow[b]{2}{*}{$\begin{array}{l}\text { Test } \\
\text { Date }\end{array}$} & \multicolumn{3}{|c|}{ Test Parameters } & \multirow[b]{2}{*}{$\begin{array}{c}\text { Diagnostic Slug-Test } \\
\text { Response Model }\end{array}$} & \multirow[b]{2}{*}{$\begin{array}{c}\text { Hydrogeologic Unit } \\
\text { Tested }^{\text {(a) }}\end{array}$} \\
\hline & & $\begin{array}{l}\text { Number of } \\
\text { Slug Tests }\end{array}$ & $\begin{array}{l}\text { Depth to } \\
\text { Water } \\
\text { (m bgs) }\end{array}$ & $\begin{array}{l}\text { Depth/Test } \\
\text { Interval } \\
\text { (m bgs) }\end{array}$ & & \\
\hline 699-52-55A & $4 / 22 / 08$ & 2 & 52.97 & $\begin{array}{c}52.97-54.80 \\
(1.83)\end{array}$ & $\begin{array}{c}\text { Heterogeneous } \\
\text { Formation/Exponential- } \\
\text { Decay (over-damped) }\end{array}$ & $\begin{array}{c}\text { Lower Ringold } \\
\text { Formation/Elephant } \\
\text { Mountain Flow Top }\end{array}$ \\
\hline
\end{tabular}

Table 4.2. Slug-Test Analysis Results for BP-5 Remedial Investigation Well 699-52-55A

\begin{tabular}{|c|c|c|c|c|c|}
\hline \multirow[b]{2}{*}{$\begin{array}{l}\text { Test Well } \\
\text { Number }\end{array}$} & \multirow[b]{2}{*}{$\begin{array}{c}\text { Test } \\
\text { Number }\end{array}$} & \multirow[b]{2}{*}{ Test Zone } & \multicolumn{2}{|c|}{ Type-Curve Analysis Method } & \multirow{2}{*}{$\begin{array}{c}\text { Bouwer and Rice } \\
\text { Analysis Method } \\
\text { Hydraulic } \\
\text { Conductivity, K, } \\
(\mathrm{m} / \mathrm{d})\end{array}$} \\
\hline & & & $\begin{array}{c}\text { Hydraulic } \\
\text { Conductivity, } \\
\mathbf{K}^{(\mathbf{a})}(\mathbf{m} / \mathbf{d})\end{array}$ & $\begin{array}{c}\text { Specific } \\
\text { Storage, } \mathrm{S}_{\mathrm{s}} \\
\left(\mathrm{m}^{-1}\right)\end{array}$ & \\
\hline \multirow{4}{*}{ 699-52-55A } & SW \#1 & $\begin{array}{l}\text { Outer Zone } \\
\text { Formation }\end{array}$ & 0.23 & $1.00 \mathrm{E}-05$ & 0.20 \\
\hline & SW \#1 & $\begin{array}{l}\text { Artificially Created } \\
\text { Inner Zone } \\
\end{array}$ & NA & NA & 1.7 \\
\hline & SW \#2 & $\begin{array}{l}\text { Outer Zone } \\
\text { Formation }\end{array}$ & 0.15 & $1.00 \mathrm{E}-05$ & 0.13 \\
\hline & SW \#2 & $\begin{array}{l}\text { Artificially Created } \\
\text { Inner Zone }\end{array}$ & NA & NA & 1.4 \\
\hline
\end{tabular}

\subsection{Well 699-52-55A}

The borehole geology log (Appendix B) indicates that the test-interval section lies within sediments of the lower Ringold Formation and the underlying Elephant Mountain basalt flowtop. The lower Ringold Formation consists of gravelly sand (80\% sand and 20\% gravel) within the upper $0.37 \mathrm{~m} \mathrm{(1.2 \textrm {ft } )}$ of the test-depth interval and silty gravelly sand ( $80 \%$ sand, $15 \%$ gravel, and $5 \%$ silt) within the underlying $0.67 \mathrm{~m}$ (2.2 ft) of the test-depth interval. The Elephant Mountain basalt flowtop consists of 
basalt containing 20 to $25 \%$ sand within the bottom $0.79 \mathrm{~m}(2.6 \mathrm{ft})$ of the test-depth interval. The basalt flowtop unit was included as part of the effective test-interval length for the analysis because the flowtop unit is hydraulically communicative (i.e., pressure responses act dynamically to barometric pressure fluctuations and water-level response trends) with the unconfined aquifer (Spane and Newcomer 2004). This is consistent with the testing approach for characterization of Hanford formation sediments overlying the basalt flowtop at the nearby Liquid Effluent Retention Facility in the 200-East Area (Spane and Newcomer 2004).

Two slug withdrawal tests (one low-stress and one high-stress test) were conducted between 1036 hours and 1400 hours (Pacific Daylight Time [PDT]), April 22, 2008, after the well was constructed and developed in January 2008. The slug tests were conducted with two different sized slugging rods that were fully submerged in the water column; one with a fully submerged volume of $0.0035 \mathrm{~m}^{3}\left(0.125 \mathrm{ft}^{3}\right)$ and a larger one with a fully submerged volume of $0.0092 \mathrm{~m}^{3}\left(0.326 \mathrm{ft}^{3}\right.$ ) (see Appendix $\mathrm{C}$ for slugging rod dimensions). These fully submerged slug-rod volumes imparted a theoretical applied stress level of

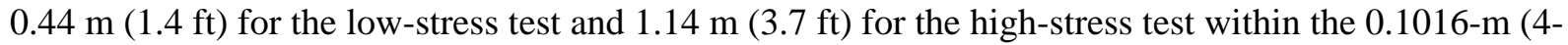
in.) I.D. well screen. Downhole test-interval response pressures during testing were monitored with a 0to 34.5-Pa (0- to 5-psig) pressure transducer set at a depth of 56-m ( 184-ft) bgs. The static depth-towater for the test interval measured before testing was $52.97 \mathrm{~m}(173.79 \mathrm{ft}) \mathrm{bgs}$.

A diagnostic analysis of slug tests conducted for this test/depth interval indicates a heterogeneous formation response condition (i.e., radial variation of hydraulic properties with distance from the well), as shown by a selected derivative plot in Figure 4.1. This test pattern exhibits an inner, radial-zone response during the initial fast-recovery portion of the test (i.e., higher permeability) that transitions to a slower test response (i.e., lower permeability) for the surrounding outer, radial-zone formation (Bouwer 1989). The presence of a high-permeability inner-zone reflects an artificially induced condition that was likely attributed to a sand filter pack with higher permeability. The thickness of the filter pack surrounding the well screen is $0.051 \mathrm{~m}$ ( 2 in.). Because of this artificially induced condition, only the outer-zone analysis results should be used for aquifer formation characterization at this well location.

Slug tests showing linear response characteristics for heterogeneous formation tests can be analyzed using the homogeneous formation analysis approaches described in Section 3.0 (Spane and Newcomer 2008). A comparison of the normalized, low- and high-stress, slug-test responses indicated stress dependence, with the higher stress test exhibiting a delayed test recovery (Figure 4.2). This delayed testrecovery response is attributed to a change in the effective length of the screen through which water flows into the well during the test. The observed $\mathrm{H}_{\mathrm{o}}$ value for the high-stress test was $\sim 60 \%$ of the effective screen length, which is too large for analyzing slug tests conducted in wells screened across the water table, particularly in thin aquifers such as the case at well 699-52-55A, using approaches for homogeneous formation analyses (Butler 1998). The high-stress test results indicate a test response approaching a non-linear test condition, as shown by the slightly concave downward plot in Figure D.3. For this reason, the low-stress slug-test results (observed $\mathrm{H}_{\mathrm{o}}$ value $\sim 25 \%$ of effective screen length), analyzed quantitatively using the approach for homogeneous formation analysis described in Butler (1998), provide a more reliable estimate of K than for the K estimate provided by the high-stress test analysis results.

For the homogeneous formation analysis, the standard type-curve method provided aquifer formation $\mathrm{K}$ estimates ranging from $0.15 \mathrm{~m} / \mathrm{d}(0.49 \mathrm{ft} / \mathrm{d})$ for the high-stress test to $0.23 \mathrm{~m} / \mathrm{d}(0.75 \mathrm{ft} / \mathrm{d})$ for the low- 
stress test. A selected example of the test-analysis plots for this well is shown in Figure 4.3. For the Bouwer and Rice method, estimates of $K$ for the outer-zone ranged between $0.13 \mathrm{~m} / \mathrm{d}(0.43 \mathrm{ft} / \mathrm{d})$ for the high-stress test and $0.20 \mathrm{~m} / \mathrm{d}(0.66 \mathrm{ft} / \mathrm{d})$ for the low-stress test, $10 \%$ lower than estimates obtained for the type-curve method. A selected example of the Bouwer and Rice analysis plot for this well is shown in Figure 4.4. The reason for the close correspondence between the estimates is that the test interval is relatively thin, and therefore the aquifer behaves as an inelastic formation. This is consistent with previous comparisons between estimates using these slug-test analysis methods, as reported in Butler (1998). The estimates of hydraulic conductivity for the effective test-interval length at well 699-52-55A represent composite values for the lower Ringold Formation and the underlying Elephant Mountain basalt flow top. These moderately low estimates of hydraulic conductivity and a relatively thin test interval at well 699-52-55A indicate that the unconfined aquifer is not very transmissive at this well location compared to most other well locations in the general 200-East Area, such as reported in Spane et al. (2001), Spane et al. (2003b), and Spane and Newcomer (2004). As noted previously, the low-stress, outer-zone test results are considered to be more representative estimates of $\mathrm{K}$ for the aquifer formation.

Estimates of $\mathrm{K}$ for the inner-zone ranged from 1.4 to $1.7 \mathrm{~m} / \mathrm{d}$ (4.6 to $5.6 \mathrm{ft} / \mathrm{d}$ ) for the high- and lowstress tests, respectively. A selected example of the Bouwer and Rice analysis plots for the inner zone is shown in Figure 4.5. This high-permeable inner radial zone reflects an artificially induced condition that was attributed to a sand filter pack with higher permeability than the outer-zone formation. The plots for the high-stress test analysis for this well are provided in Appendix D. 


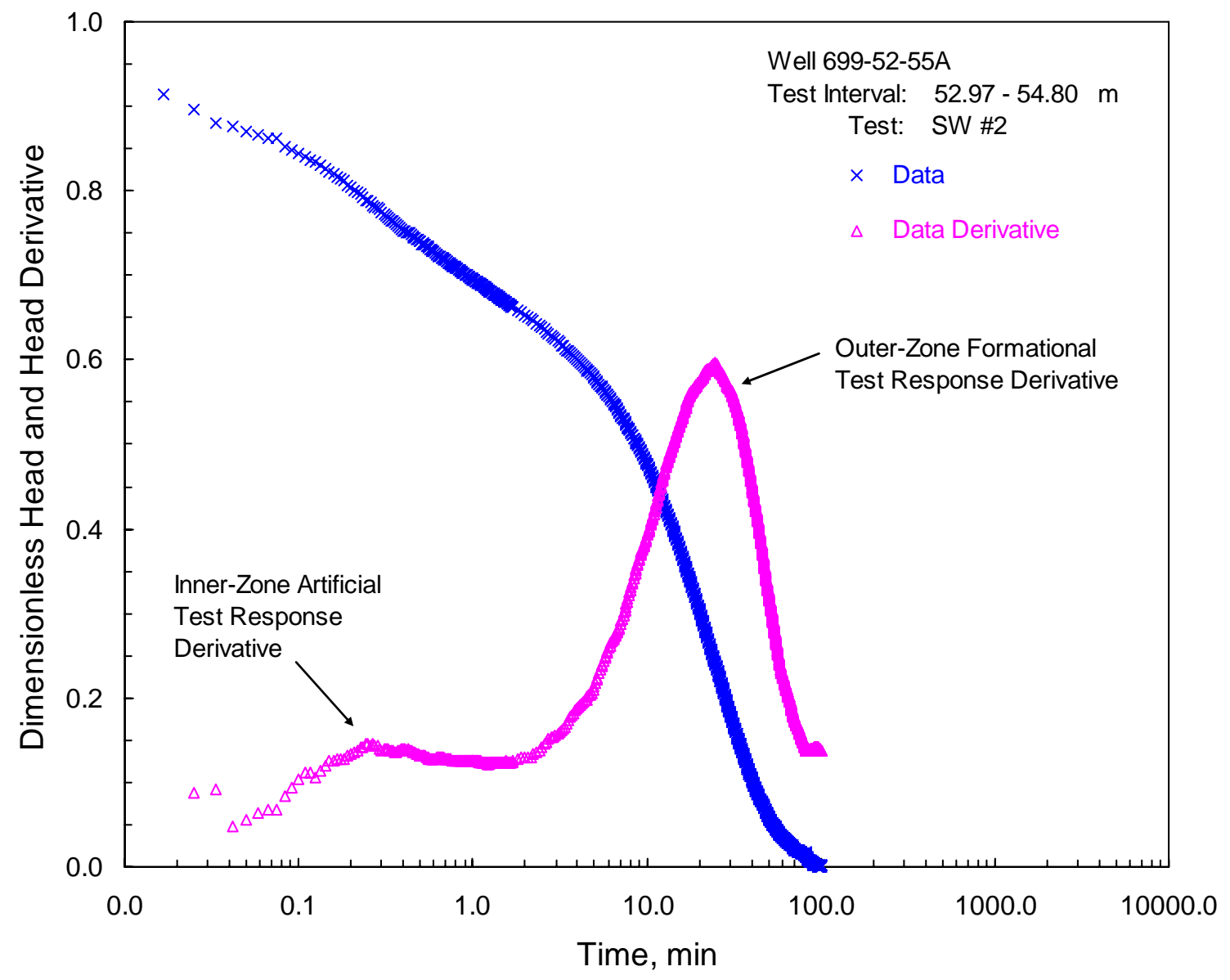

Figure 4.1. Diagnostic Analysis Plot for Well 699-52-55A 


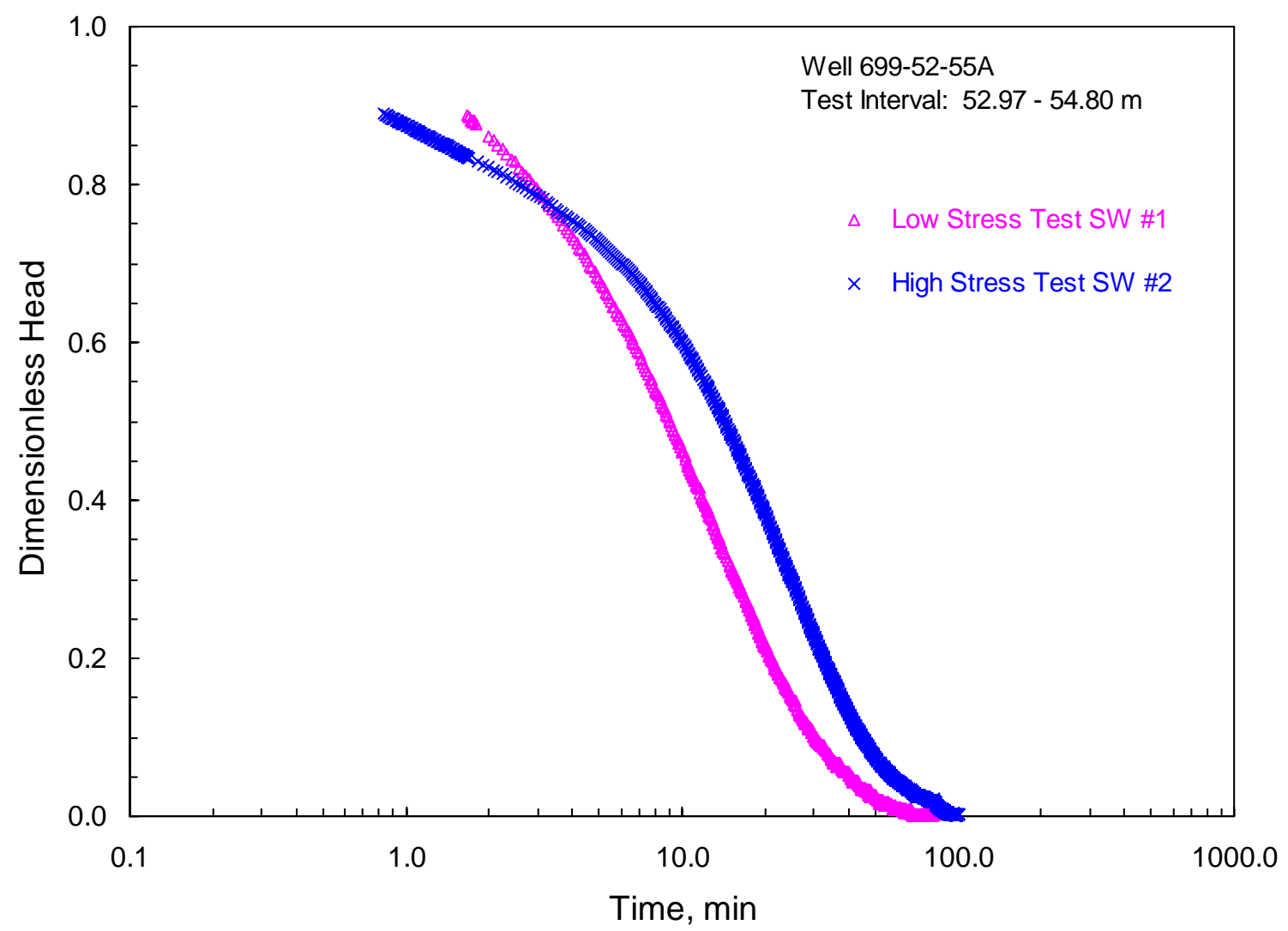

Figure 4.2. Comparison of Low-Stress and High-Stress Slug-Test Responses for Well 699-52-55A 


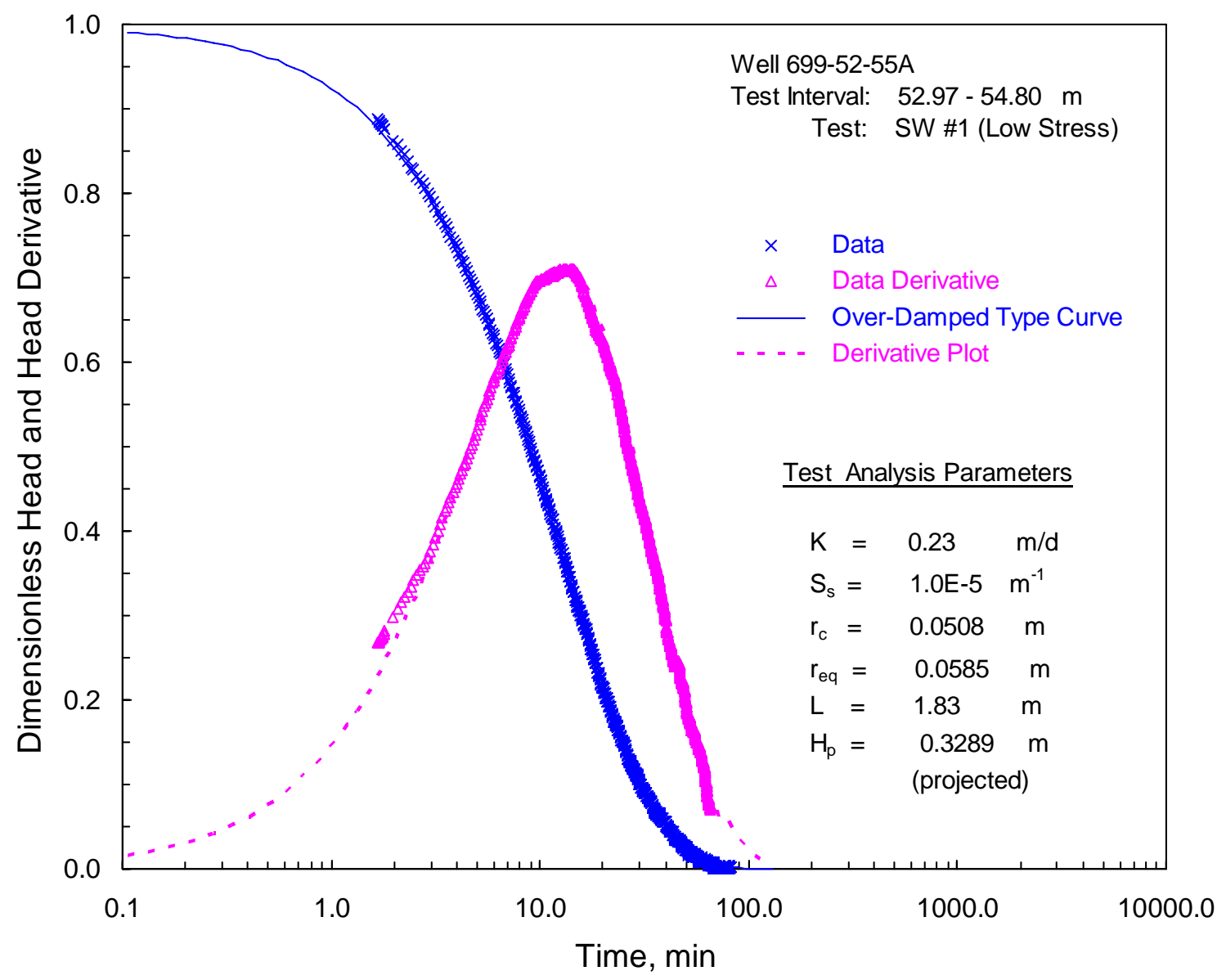

Figure 4.3. Selected Type-Curve Analysis Plot for Well 699-52-55A 


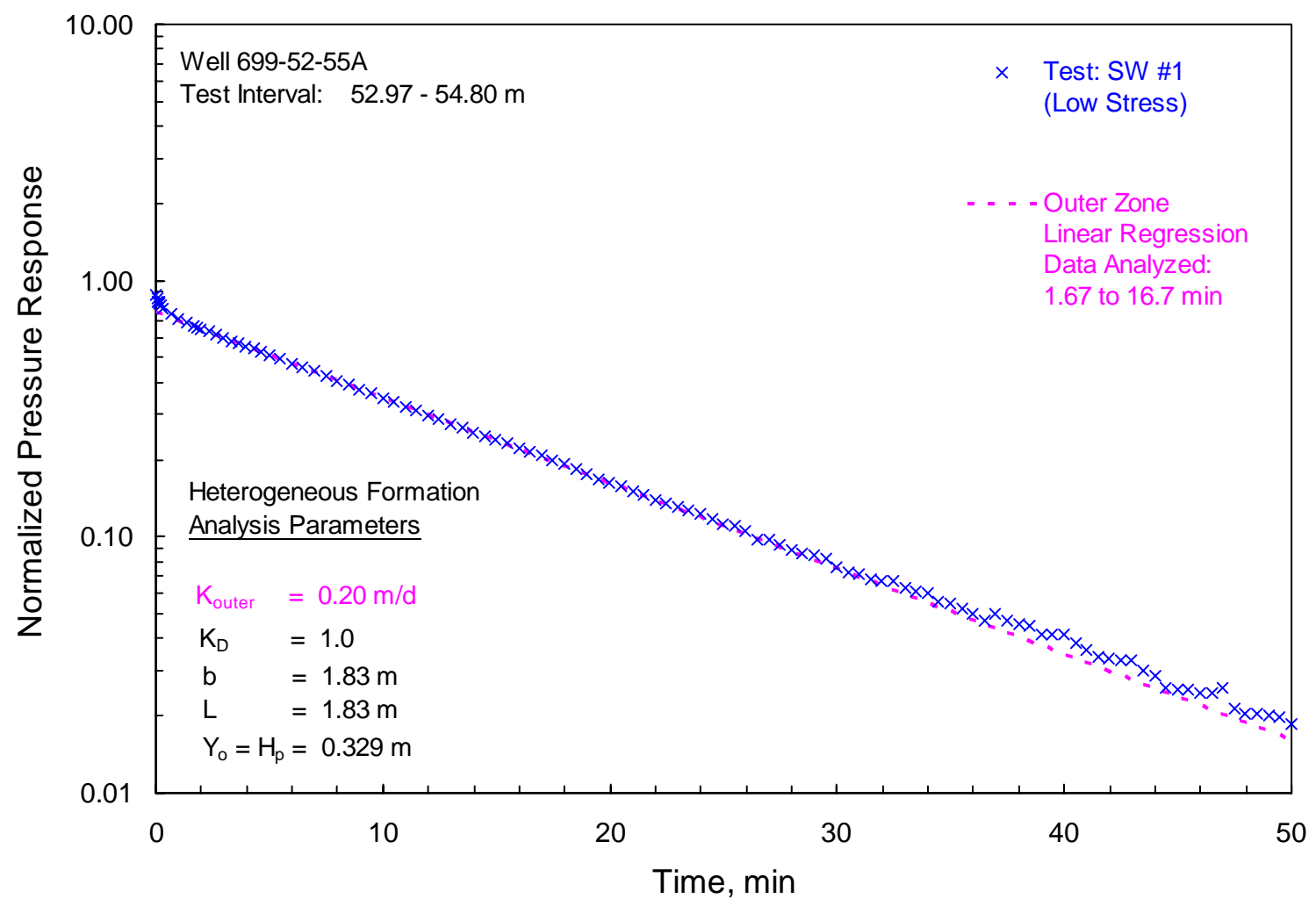

Figure 4.4. Selected Bouwer and Rice Analysis Plot for Outer Zone, Well 699-52-55A 


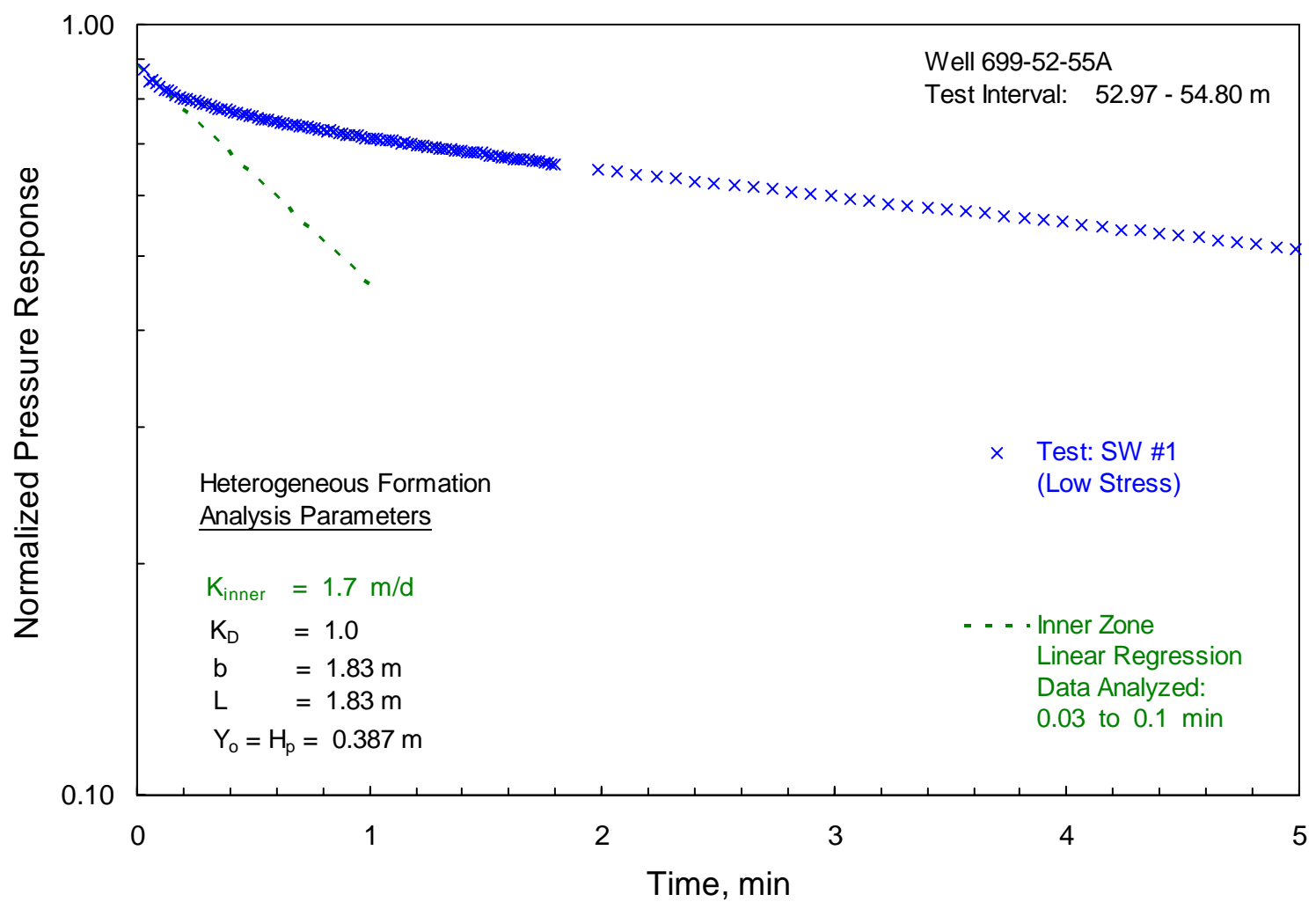

Figure 4.5. Selected Bouwer and Rice Analysis Plot for Inner Zone, Well 699-52-55A 


\subsection{Conclusions}

Two slug-withdrawal tests using two different sized slug rods were conducted within a test/depth interval in the final, completed BP-5 well 699-52-55A. The test/depth interval represents the upper $1.83 \mathrm{~m}(6.0 \mathrm{ft})$ of the unconfined aquifer that is composed of sediments of the lower Ringold Formation within the upper $1.04 \mathrm{~m}$ (3.4 ft) and the Elephant Mountain basalt flowtop within the lower $0.79 \mathrm{~m}$ $(2.6 \mathrm{ft})$. The basalt flowtop unit was included as part of the effective test-interval length for the analysis because the flowtop unit is hydraulically communicative with the unconfined aquifer. Estimates of hydraulic conductivity for this effective test-interval length represent composite values for the lower Ringold Formation and underlying basalt flowtop unit.

The slug-test analyses indicated a heterogeneous formation, exponential decay (over-damped) response pattern with moderately low permeability test conditions. The low-stress slug-test analyses provided the most reliable estimates of hydraulic conductivity because of stress-dependence delayed effects and a slightly non-linear test response associated with the high-stress test. This non-linear test condition was attributed to an observed initial displacement that was too high a percentage of the effective screen length for a well screen completed across the water table in a thin aquifer. For the results of the low-stress test analysis, a hydraulic conductivity value of $0.23 \mathrm{~m} / \mathrm{d}(0.75 \mathrm{ft} / \mathrm{d})$ for the aquifer formation was estimated by the method of type-curve-matching analysis, and a value of $0.20 \mathrm{~m} / \mathrm{d}(0.66 \mathrm{ft} / \mathrm{d})$ was estimated by the Bouwer and Rice analysis method. Hydraulic-conductivity estimates obtained with the Bouwer and Rice analytical method correspond within 10\% of the estimates obtained with the type-curve method due to a relatively thin, inelastic test interval. These moderately low estimates of hydraulic conductivity and a relatively thin test interval at well 699-52-55A indicate that the unconfined aquifer is not very transmissive at this well location compared to most other well locations in the general 200-East Area. An estimate for low-stress, slug-test hydraulic conductivity for the inner zone, attributed to a higher-permeability sand filter pack, was 1.7 m/d (5.6 ft/d) using the Bouwer and Rice analysis method. 


\subsection{References}

Bouwer H. 1989. “The Bouwer and Rice slug test - an update.” Ground Water 27(3):304-309.

Bouwer H, and RC Rice. 1976. “A slug test for determining hydraulic conductivity of unconfined aquifers with completely or partially penetrating wells.” Water Resources Research 12(3):423-428.

Butler JJ, Jr. 1998. The Design, Performance, and Analysis of Slug Tests. Lewis Publishers, CRC Press, Boca Raton, Florida.

Butler JJ, Jr. and EJ Garnett. 2000. Simple procedures for analysis of slug tests in formations of high hydraulic conductivity using spreadsheet and Scientific Graphics Software. Open-file Report 2000-40, Kansas Geological Survey, Lawrence, Kansas.

Hyder Z and JJ Butler, Jr. 1995. "Slug tests in unconfined formations: An assessment of the Bouwer and Rice technique.” Ground Water 33(1):16-22.

McElwee CD. 2001. “Application of a nonlinear slug test model.” Ground Water 39(5):737-744.

McElwee CD and MA Zenner. 1998. “A nonlinear model for analysis of slug-test data.” Water Resources Research 34(1):55-66.

Spane FA, Jr., PD Thorne, and DR Newcomer. 2001. Results of Detailed Hydrologic Characterization Tests - Fiscal Year 2000. PNNL-13514, Pacific Northwest National Laboratory, Richland, Washington.

Spane FA, Jr., JJ Butler, MD White, and TJ Gilmore. 2003a. Improving Pulse/Slug interference tests for contaminated site hydraulic property characterization. SERDP Fiscal Year 2004 Research Proposal, submitted February 25, 2003.

Spane FA, Jr., DR Newcomer, and PD Thorne. 2003b. Results of Detailed Hydrologic Characterization Tests - Fiscal Year 2002. PNNL-14186, Pacific Northwest National Laboratory, Richland, Washington.

Spane FA, Jr., and DR Newcomer. 2004. Results of Detailed Hydrologic Characterization Tests - Fiscal Year 2003. PNNL-14804, Pacific Northwest National Laboratory, Richland, Washington.

Spane FA, Jr., and DR Newcomer. 2008. Results of Detailed Hydrologic Characterization Tests - Fiscal and Calendar Year 2005. PNNL-17348, Pacific Northwest National Laboratory, Richland, Washington.

Springer RK and LW Gelhar. 1991. "Characterization of large-scale aquifer heterogeneity in glacial outwash by analysis of slug tests with oscillatory response, Cape Cod, Massachusetts.” In: U.S. Geological Survey Water Resources Investigations. Report 91-4034:36-40.

Zurbuchen BR, VA Zlotnik, and JJ Butler, Jr. 2002. "Dynamic interpretation of slug tests in highly permeable aquifers.” Water Resources Research, 38(3):10.1029/2001WR000354. 


\section{Appendix A}

\section{Well Summary Sheet for Well 699-52-55A}




\section{Appendix A: Well Summary Sheet for Well 699-52-55A}

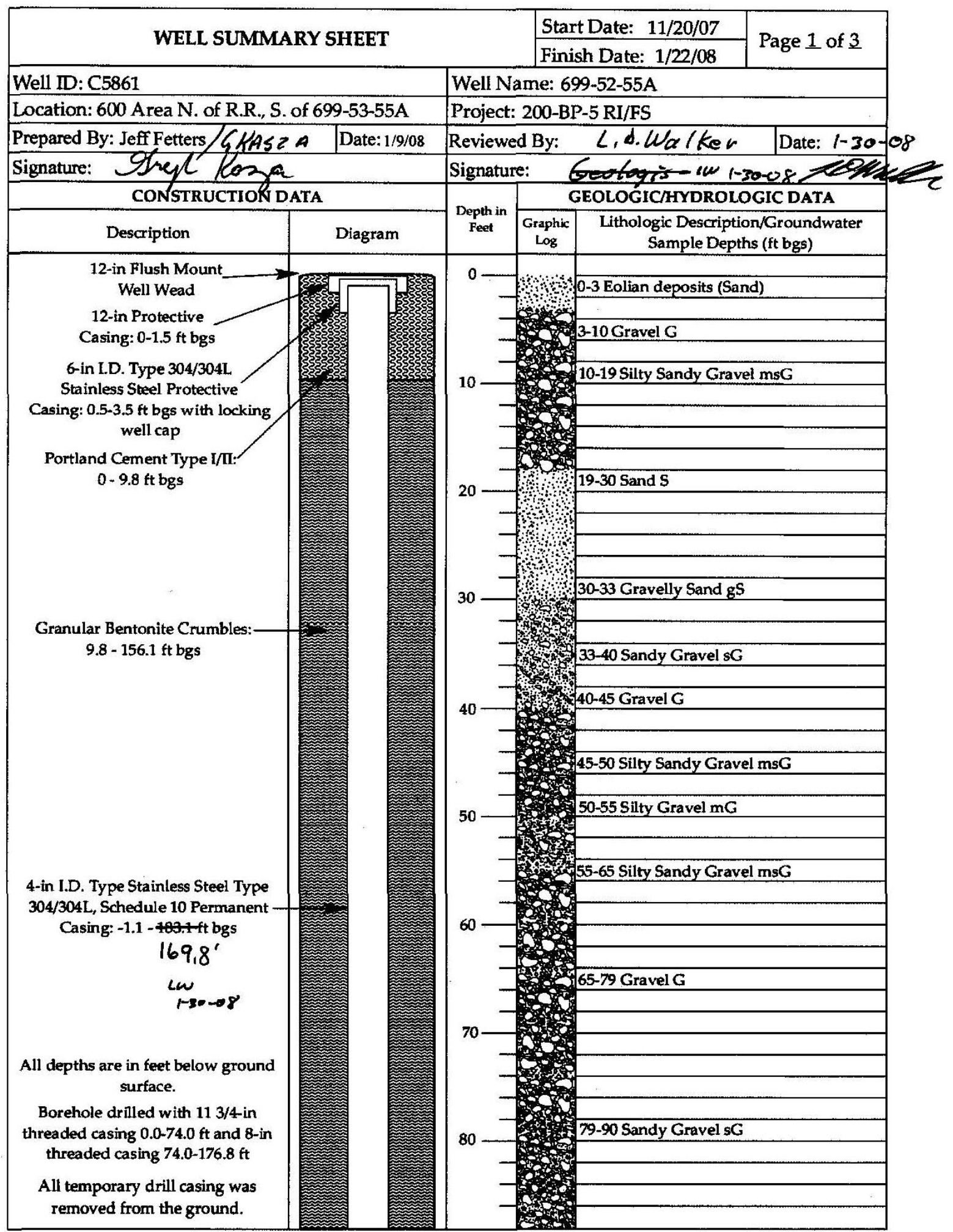




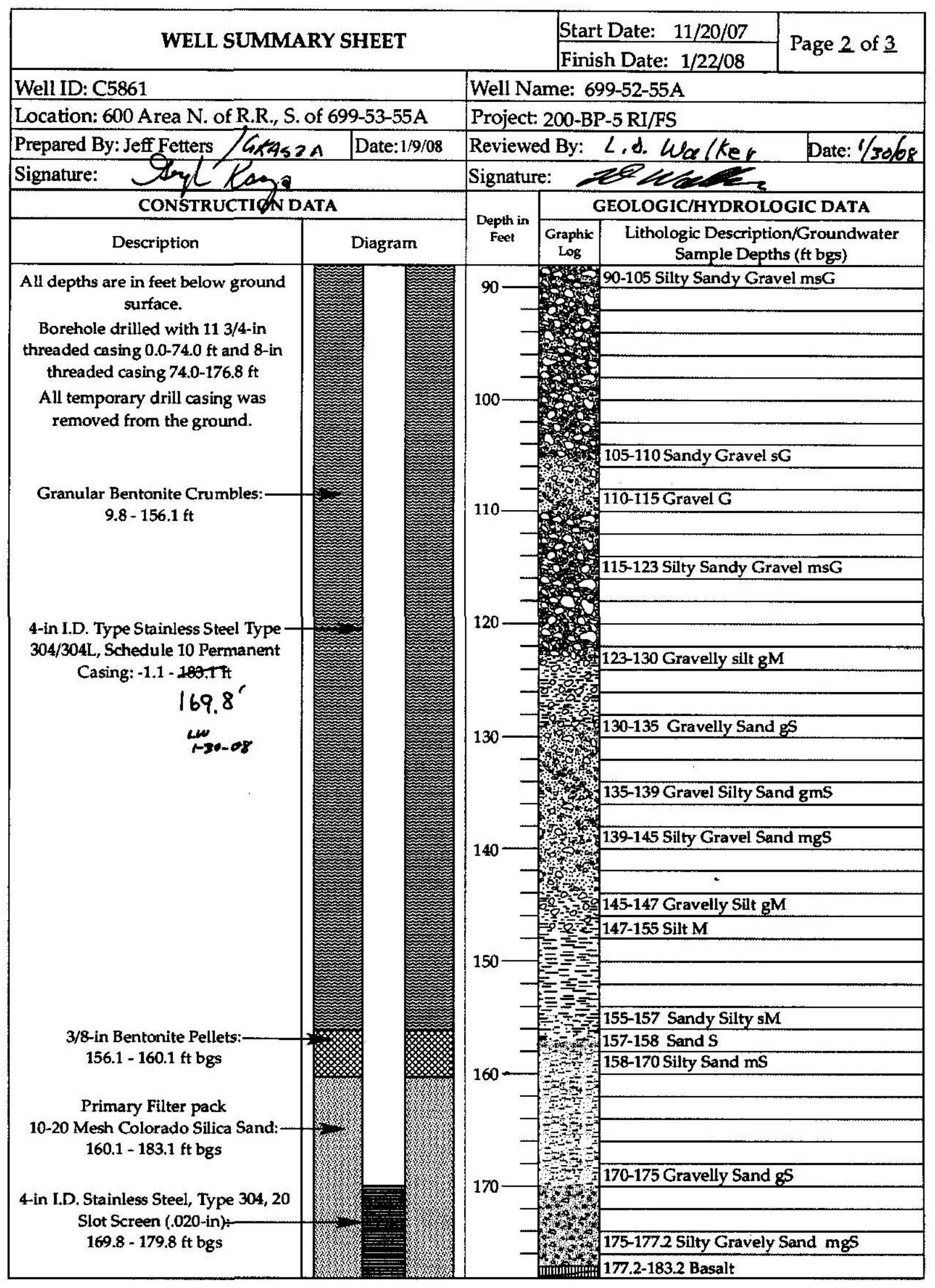




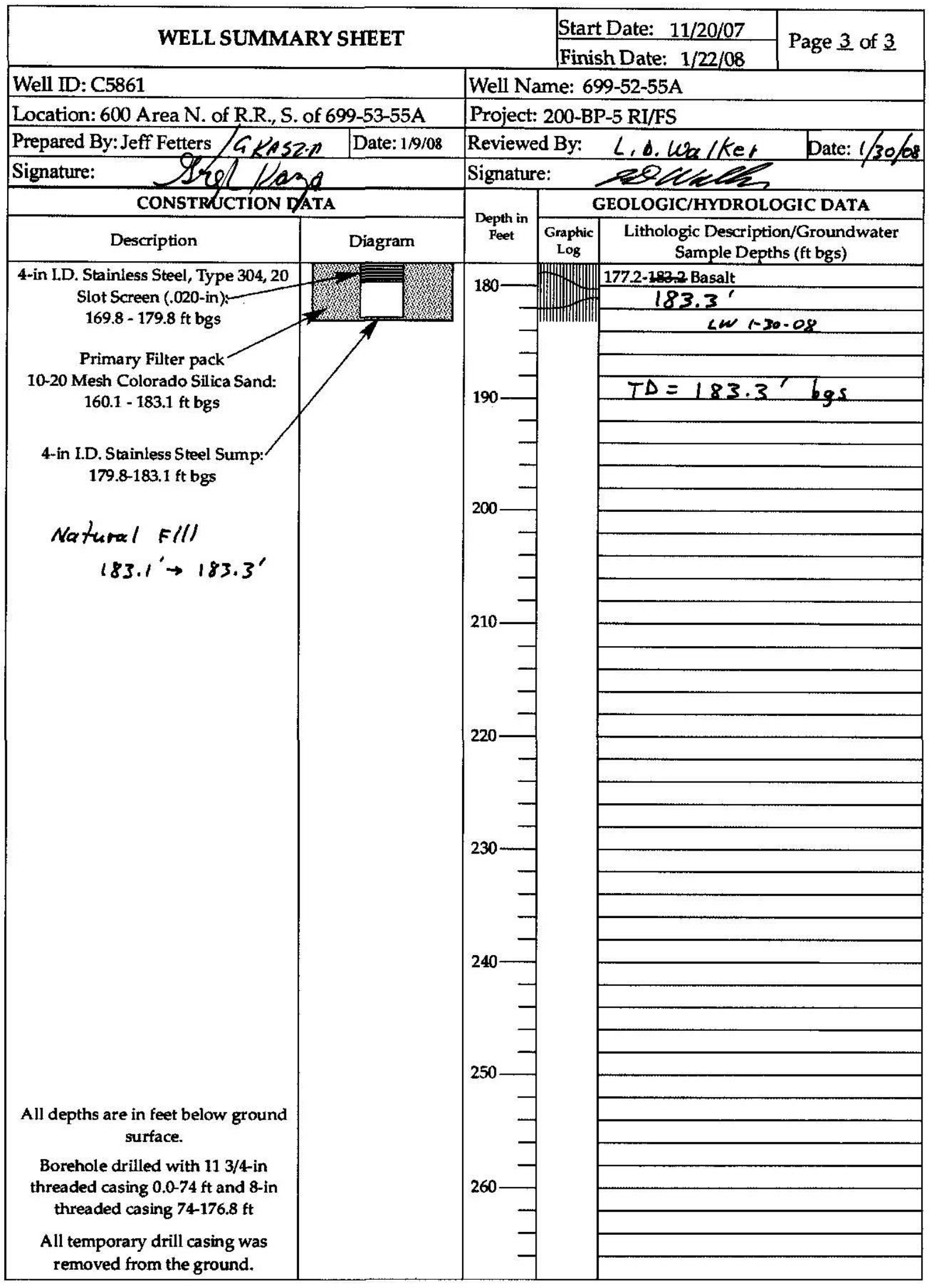




\section{Appendix B}

Borehole Log for Well 699-52-55A 


\section{Appendix B: Borehole Log for Well 699-52-55A}

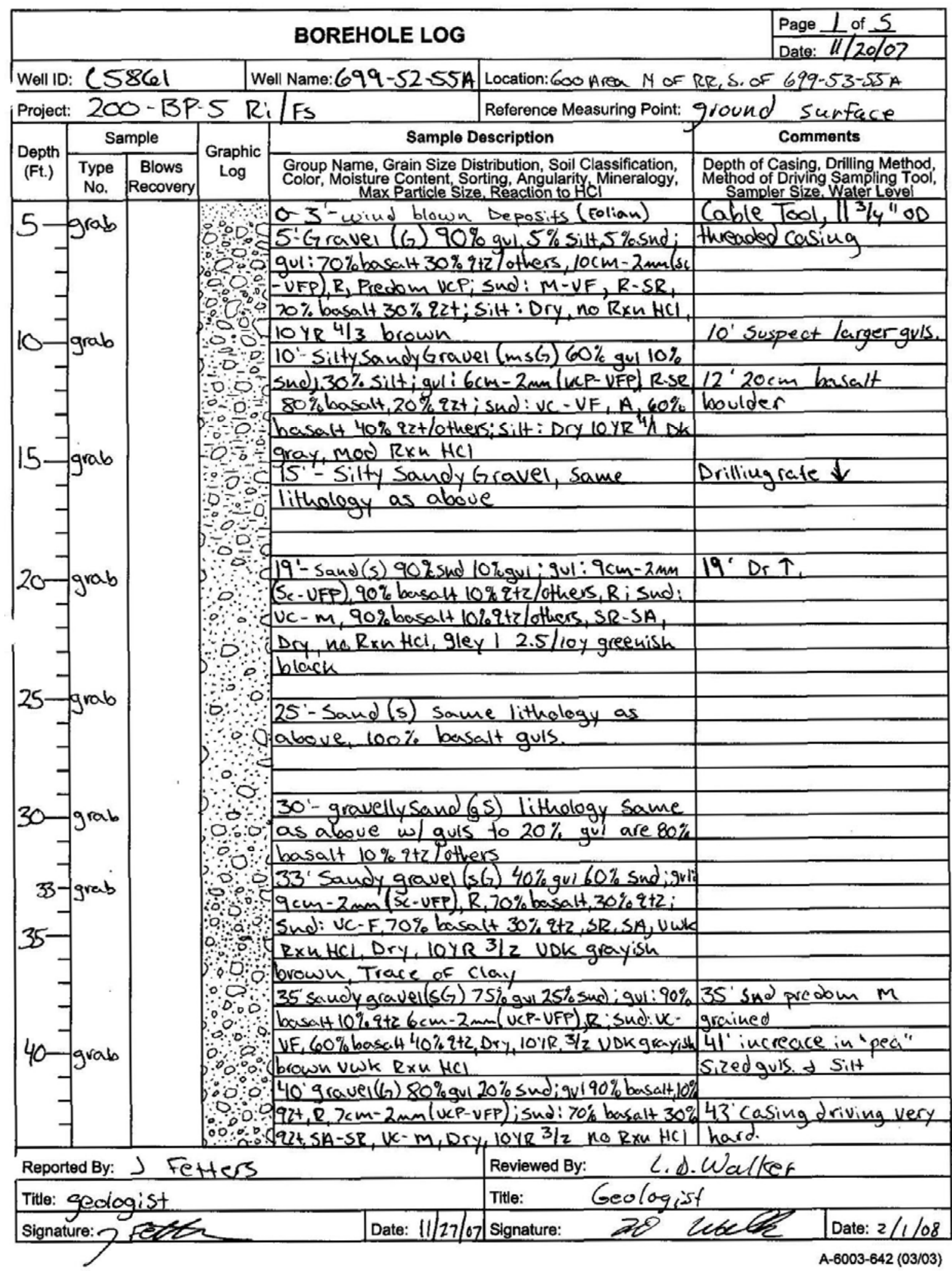




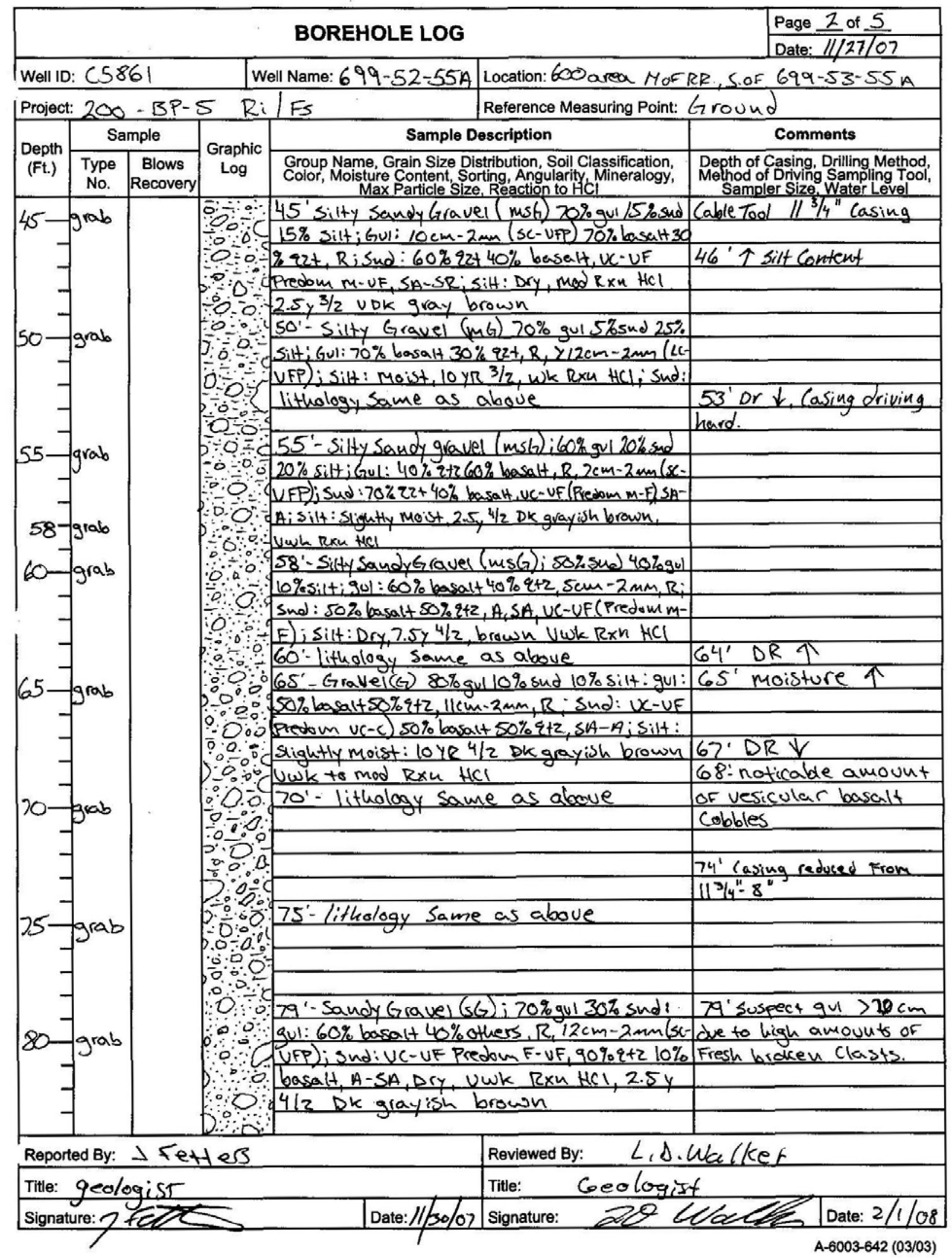




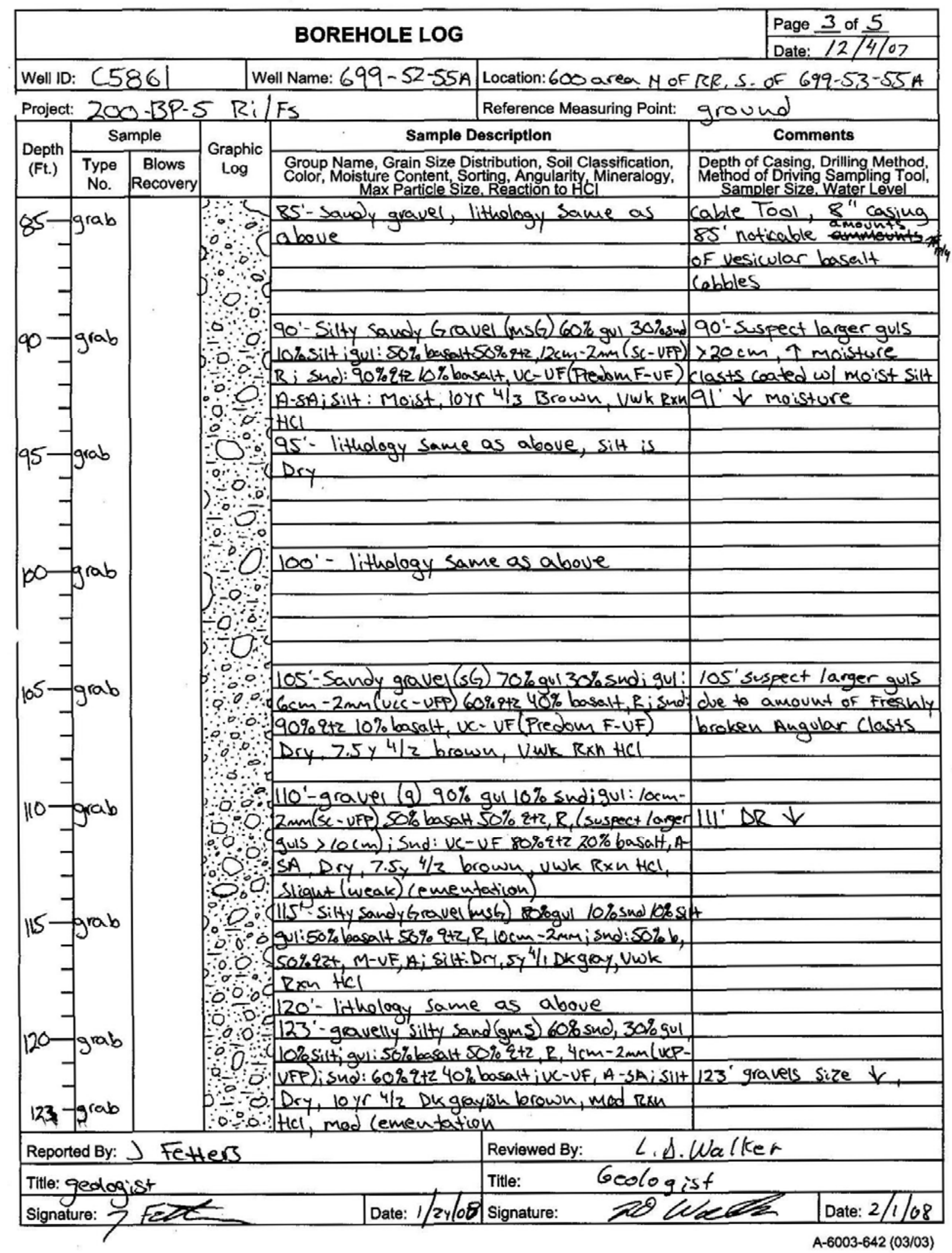




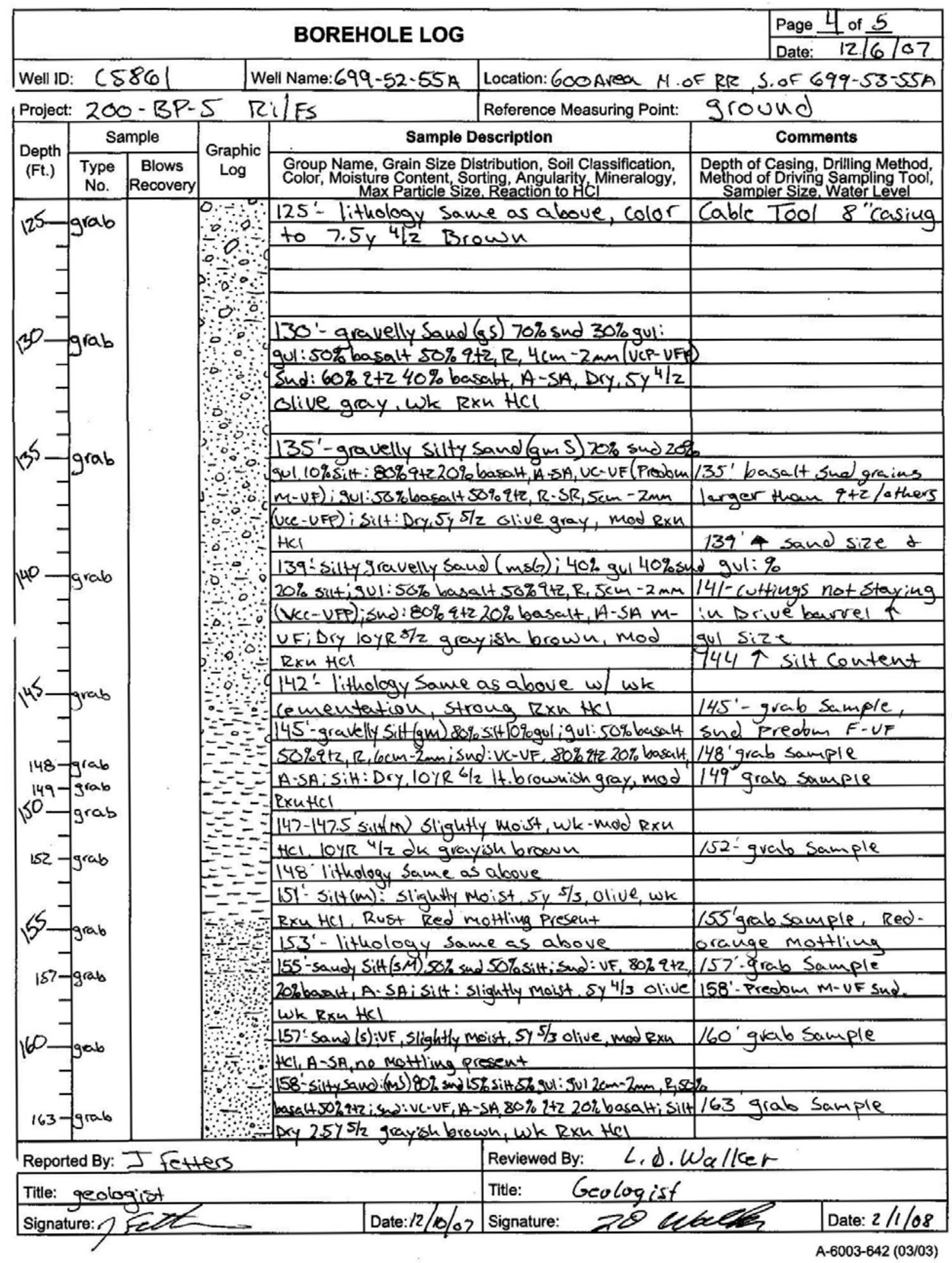




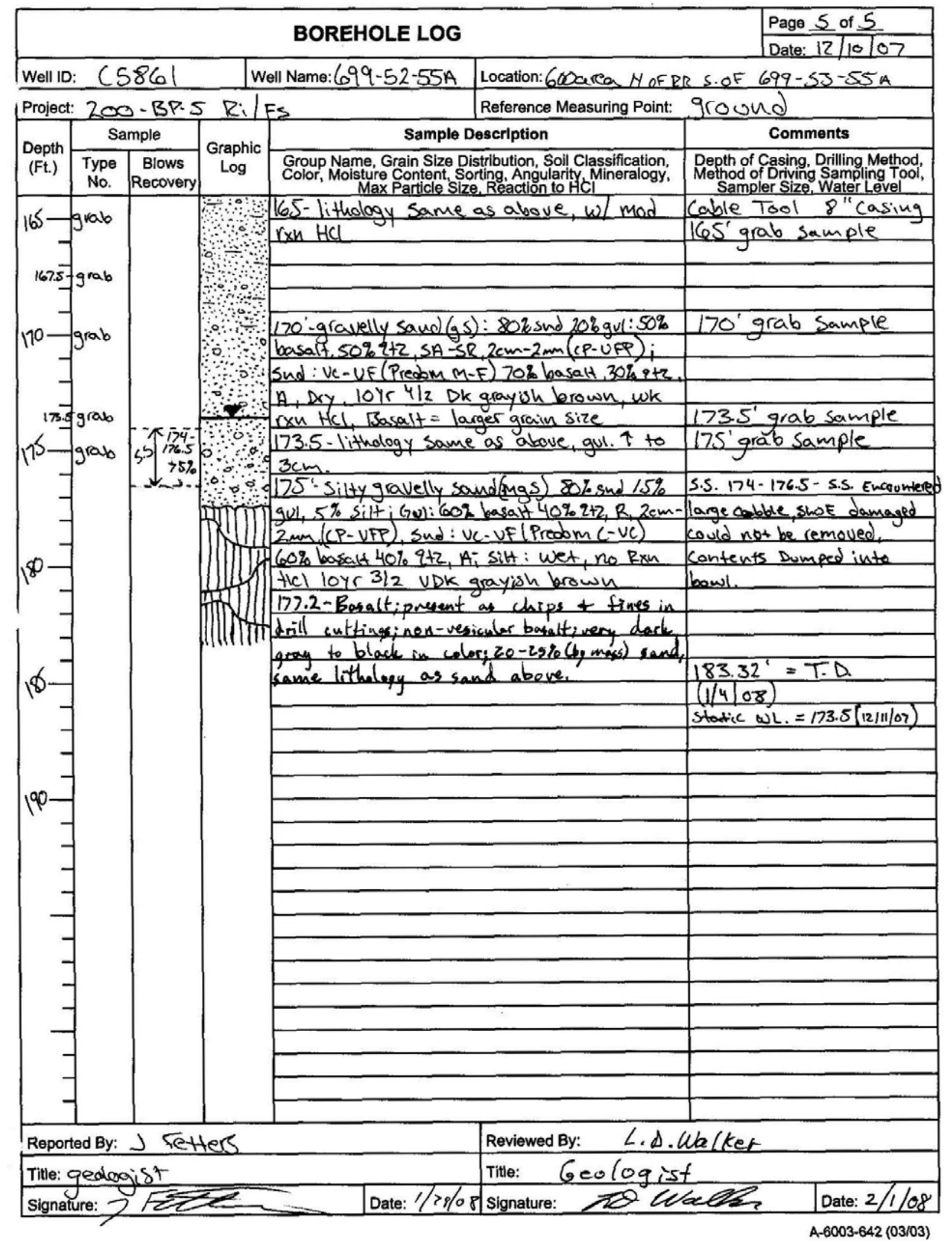




\section{Appendix C}

Slug-Test Field Notes for Well 699-52-55A 


\section{Appendix C: Slug-Test Field Notes for Well 699-52-55A}

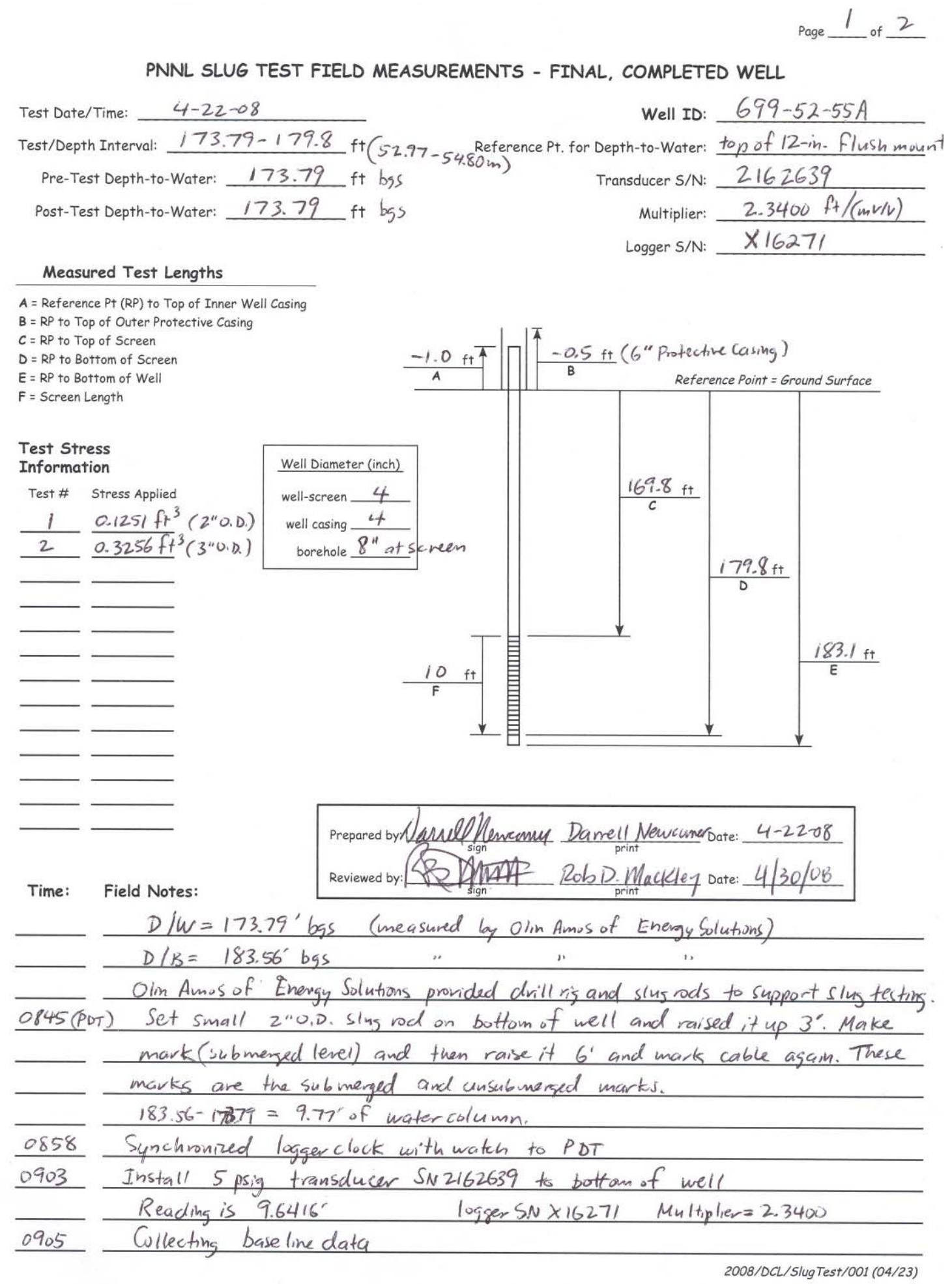

C.1 
Page 2 of 2

PNNL SLUG TEST FIELD MEASUREMENTS - FINAL, COMPLETED WELL (continuation sheet)

Test Date/Time: $\frac{4-22-08}{173.79-179.8 \mathrm{ft}}$ bgs

Well ID:

Time: Field Notes:

0920 Lower 2"O.D. slug rod into water column slowly to upper mark. Upper

mark is even with ground surface - well is flush-mounted. Rod is fully

- Recorery is very slow

- 4" ID casing is $1.0^{\prime}$ below ground surface. 6" casing is $0.5^{\prime}$ below ground

Surface.

$\frac{1025}{1033} \frac{\text { water level has recovered to } 9.76^{\prime}}{9.7505^{\prime}}$

1036 Initiate slug withdrawal test \#1;2"0.D rd raised completely out of

$\simeq 1039$ watercolumn. Lower mark at least a foot a boveground surface.

1155 Remove 2"O.D. rod from well and replace it with 3"O.D. rod.

1158 Lower 3"O.D rod into water column to upper mark. Rod is completely submerged. Lower mark was moved down 0.7' because 3"0.D rod is

6.7' long. (2"O.D. rod is 6.0' long)

1400 Initiate slug withdrawal test \#2 using 3"O.D. rod. Rod was

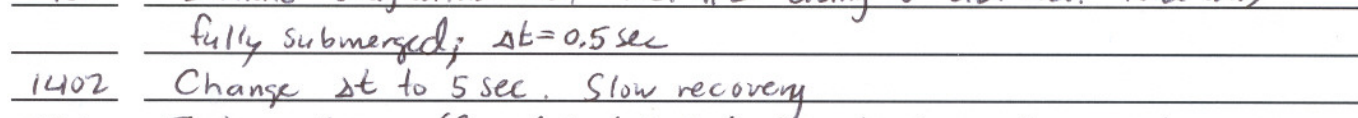

1522 Took well cap off and it disturbed water level readings a bit.

$1557 \quad D / W=52.971 \mathrm{~m} \mathrm{bgs}=173.79^{\circ} \mathrm{bgs}$ Etape \#wL3099

1602 Turn locger off. Data dounloaded to file name CR10X_X16621.6-52-55A.S1-2.dat

- $\frac{\text { and backed it up on jump drive. }}{\text { 2"O.D. rod dimensions }} \frac{\text { 3"O.D. roldimensions }}{4}$

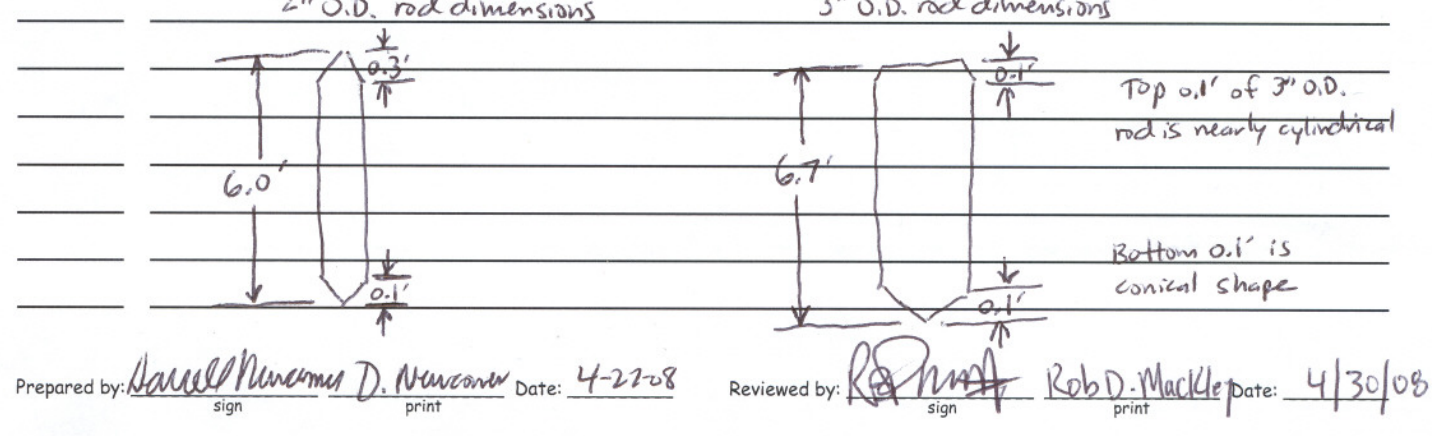

2008/DCL/S/ugTest/002 (04/23) 


\section{Appendix D}

\section{Slug-Test SW \#2 Plots for Well 699-52-55A}




\section{Appendix D: Slug-Test SW \#2 Plots for Well 699-52-55A}

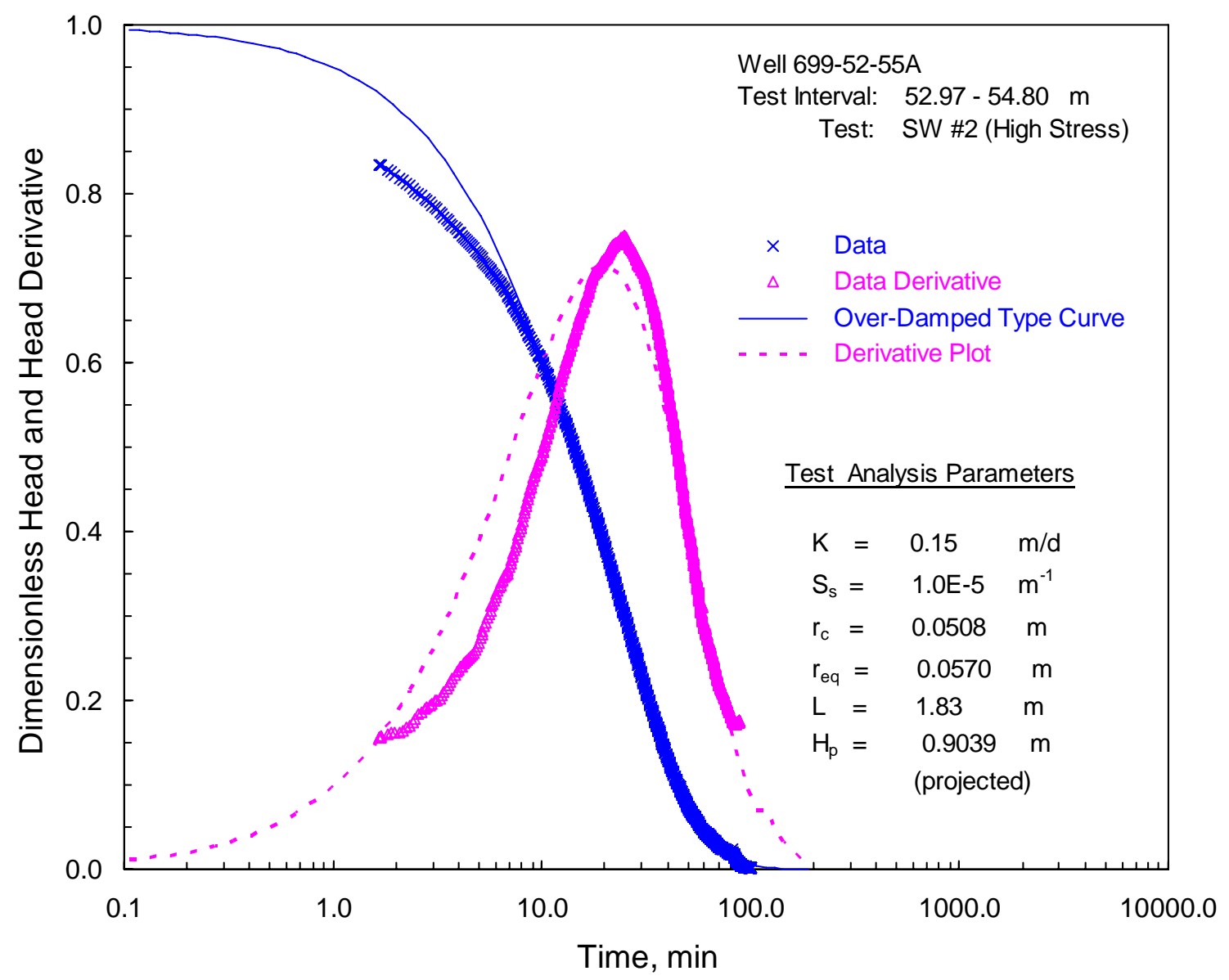

Figure D1. Type-Curve Analysis Plot for Test SW \#2, Well 699-52-55A 


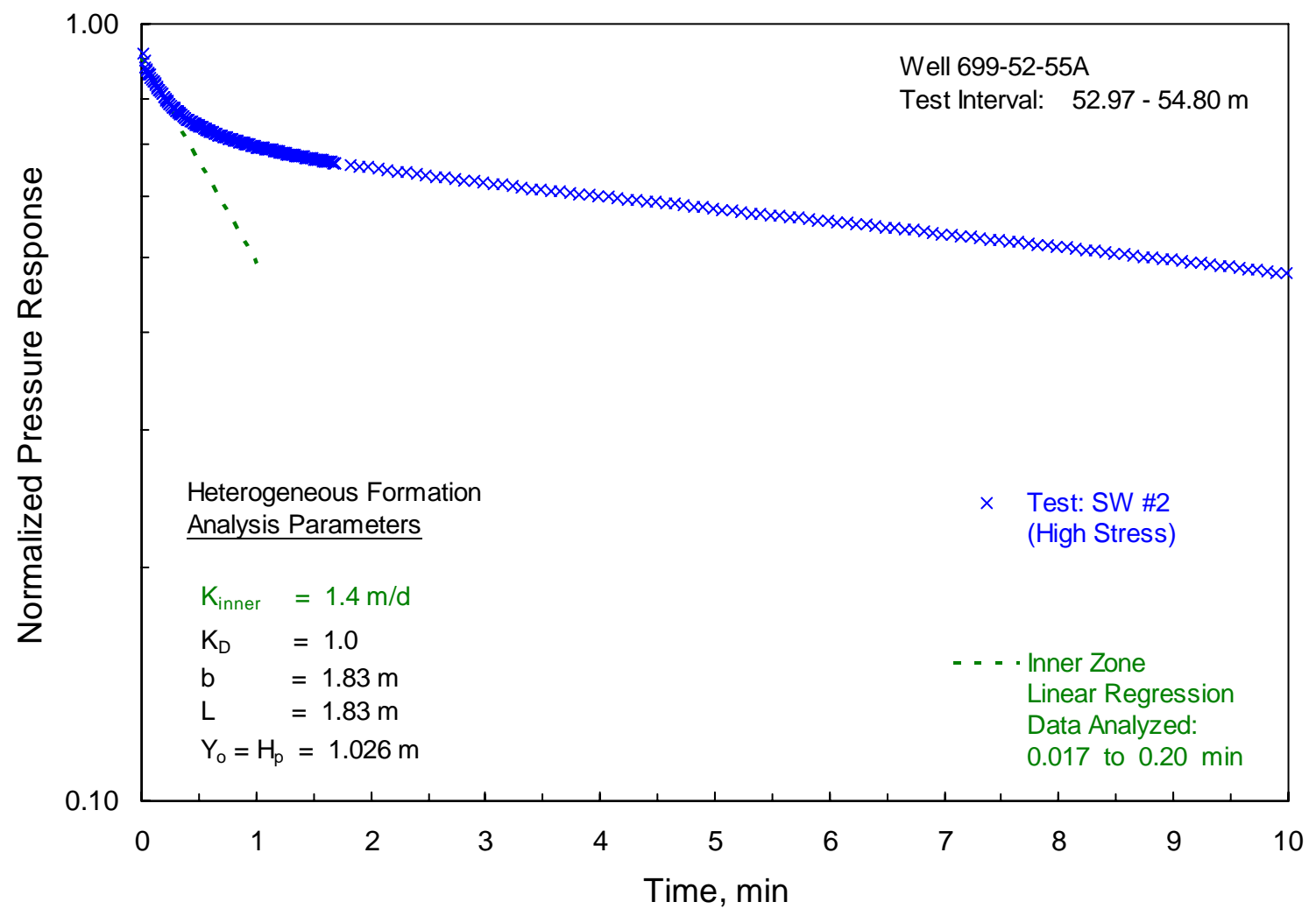

Figure D2. Bouwer and Rice Analysis Plot for Inner Zone, Test SW \#2, Well 699-52-55A 


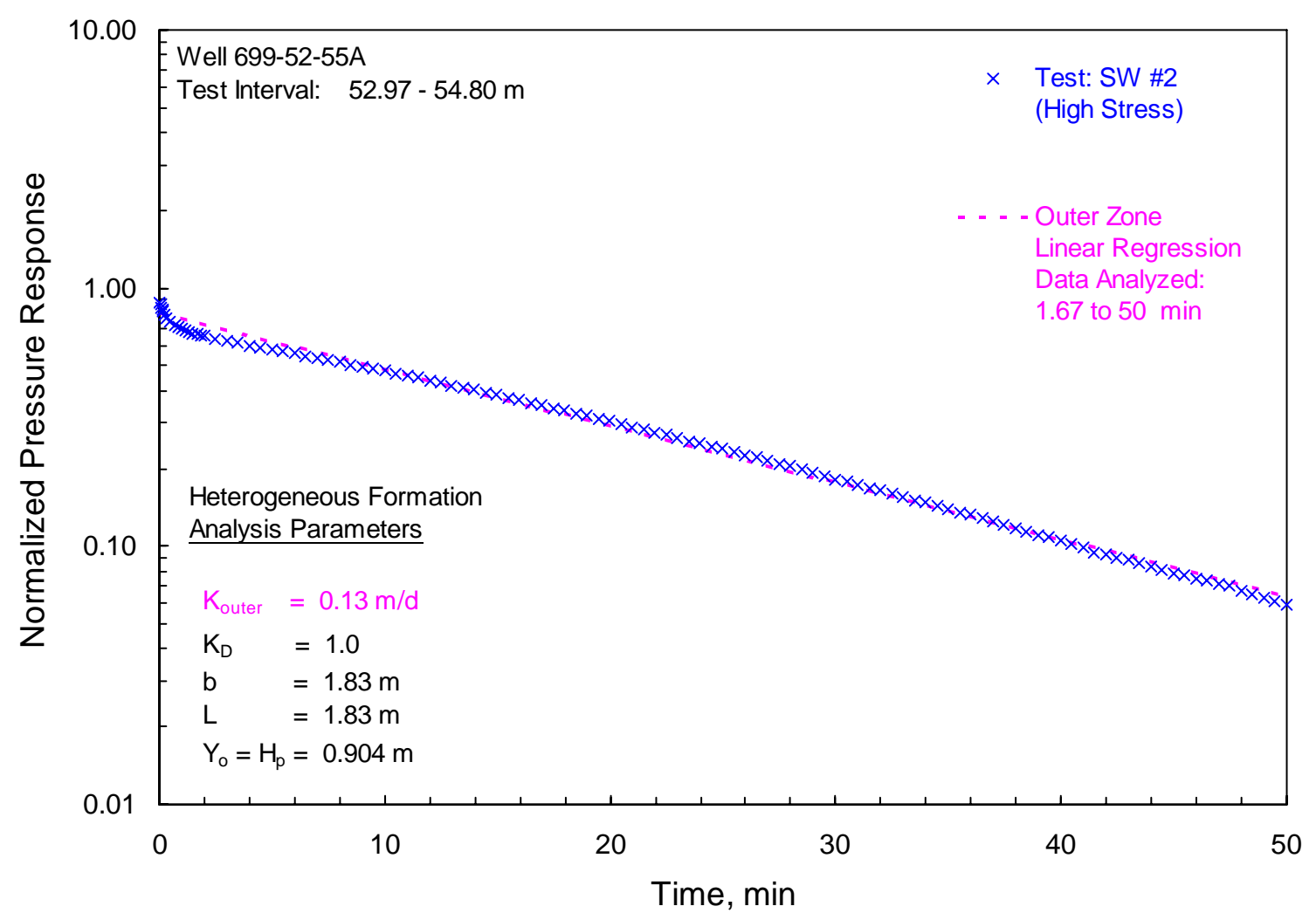

Figure D3. Bouwer and Rice Analysis Plot for Outer Zone, Test SW \#2, Well 699-52-55A 
PNNL-17675

\section{Distribution}

No. of

Copies

ONSITE

8 Pacific Northwest National Laboratory

D. R. Newcomer (5) K6-96

F. A. Spane K6-96

Hanford Technical Library (2) P8-55

8 Fluor Hanford, Inc.

R. S. Edrington E6-35

D. S. Miller E6-44

S. M. Narbutovskih E6-44

L. C. Swanson E6-35

G. S. Thomas (2) E6-44

B. A. Williams E6-44

C. S. Wright E6-35

Distr. 1 